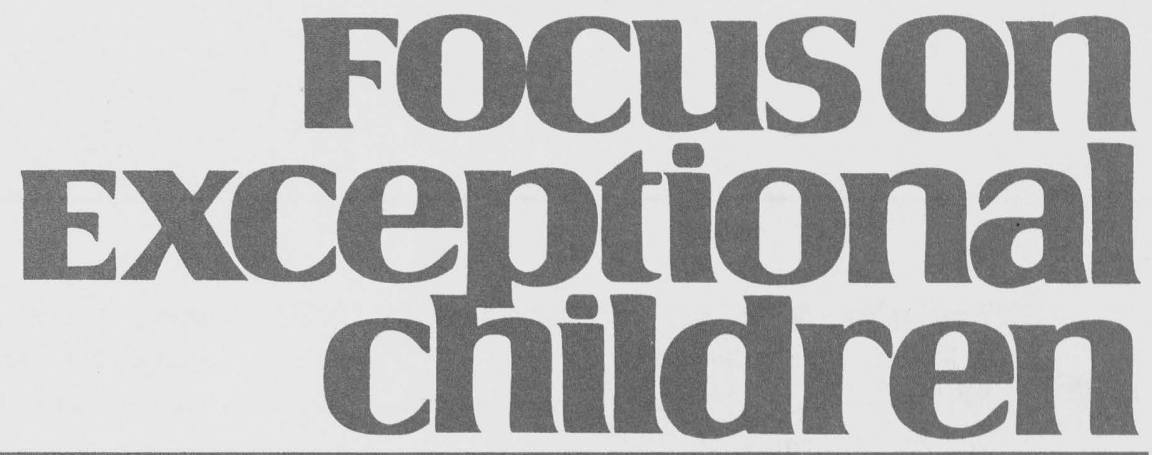

\title{
Validated Practices for Teaching Mathematics to Students With Learning Disabilities: A Review of Literature
}

\author{
Susan Peterson Miller, Frances M. Butler, and Kit-hung Lee
}

Teaching mathematics to students with learning disabilities continues to be a challenge for teachers in today's schools. The prevalence of arithmetic disability is estimated to be at least $6 \%$ of the general population (Badian, 1983). A significant number of students with learning disabilities exhibit specific difficulties with mathematics. At least one fourth of students with learning disabilities are identified for special education services due to significant discrepancies primarily between aptitude and mathematics performance (Brian, Bay, Lopez-Reyna, and Donahue, 1991). In another study, teachers reported that $26 \%$ of their students with learning disabilities received special education services primarily for mathematical difficulties encountered in the general education curriculum (McLeod \& Armstrong, 1982). The findings from this survey also revealed that, of students with learning disabilities in the sixth grade and higher, two of three received special instruction in math. Numerous researchers have reported that students with disabilities have extensive problems with mathematics computation and problem solving. Specifically, it has been noted that:

- 8- and 9-year olds with learning disabilities performed at about a first-grade level on computation and application (Cawley \& Miller, 1989);

- students with learning disabilities, aged 9 through 14 , demonstrated very little progress in computation from one year to the next (Cawley, Parmar, Yan, \& Miller, 1998);

- students with learning disabilities progressed approximately 1 year for every 2 years of school attendance (Cawley \& Miller, 1989);

- adolescents with learning disabilities made an average of 1 year's growth during Grades 7 through 12 (Warner, Alley, Schumaker, Deshler, \& Clark, 1980);

- 12 th grade students with learning disabilities performed at high fifth-grade level (Cawley \& Miller, 1989; Warner et al., 1980);

- students with learning disabilities experienced even greater difficulty in math than their peers without disabilities (Ackerman, Anhalt, \& Dykman, 1986; Cawley,

The authors are all with the University of Nevada, Las Vegas. 
Parmar, Yan, \& Miller, 1996; Cawley, Parmar, Yan, \& Miller, 1998; Fleischner, Garnett, \& Shepherd, 1982; Goldman, 1989; Lee \& Hudson, 1981; McLeod \& Armstrong, 1982).

Thus, there is little debate with regard to the need for quality instruction in math for students with learning disabilities. Fortunately, the amount of research related to effective math instruction for students with disabilities has increased over the past decade.

Mastropieri, Scruggs, and Shiah (1991) reviewed research conducted from 1975 to 1988 involving mathematics instruction for students with learning disabilities. They identified 30 studies and found data-based support for behavioral and cognitive interventions including reinforcement; modeling, demonstration, and feedback; self-instruction and goal-setting; cognitive and mnemonic strategies; cognitive behavior modification; instructional sequences; peer mediation; and computer-assisted instruction. The purpose of this

\section{Focuson
Exceptional
childiren}

ISSN 0015-511X FOCUS ON EXCEPTIONAL CHILDREN (USPS 203-360) is published monthly except June, July, and August as a service to teachers, special educators, curriculum specialists, administrators, and those concerned with the special education of exceptional children. This publication is annotated and indexed by the ERIC Clearinghouse on Handicapped and Gifted children for publication in the monthly Current Index to Journals in Education (CIJE) and the quarterly index, Exceptional Children Education Resources (ECER). The full text of Focus on Exceptional Children is also available in the electronic versions of the Education Index. It is also available in microfilm from Xerox University Microfilms, Ann Arbor, MI. Subscription rates: Individual, $\$ 30$ per year; institutions, $\$ 40$ per year. Copyright (C) 1998, Love Publishing Company. All rights reserved. Reproduction in whole or part without written permission is prohibited. Printed in the United States of America. Periodicals postage is paid at Denver, Colorado. POSTMASTER: Send address changes to:

$$
\begin{gathered}
\text { Love Publishing Company } \\
\text { Executive and Editorial Office } \\
\text { P.O. Box } 22353 \\
\text { Denver, Colorado } 80222 \\
\text { Telephone (303) 221-7333 }
\end{gathered}
$$

Edward L. Meyen University of Kansas
Glenn A. Vergason Georgia State University

Richard J. Whelan University of Kansas Medical Center
Stanley F. Love Publisher
Thomas S. Love Associate Editor article is to extend the work of Mastropieri et al. and provide an updated literature review related to validated math practices for students with learning disabilities.

\section{LITERATURE REVIEW PROCEDURES}

A systematic search through three computerized databases-Education Resources Information Center, Psychological Abstracts, and Dissertation Abstract Internationalwas conducted. The following descriptors were used: research, mathematics, mathematics education, mathematics instruction, disabilities, learning disabilities, special education, special education population, intervention, strategies, computation, problem solving, counting, number facts, addition, subtraction, multiplication, division, fractions, mnemonic, constant time delay, feedback, modeling, selfregulation, self-monitoring, peer tutoring, precision teaching, technology, computer-assisted instruction, computer, and calculators.

Next, a manual search of the latest issues (1997-98) of journals that emerged from the computerized search took place. Included among the manual journal search were: Cognition and Instruction (1998 only), Computers in the Schools (1997 only), Educational Studies in Mathematics, Exceptional Children, Focus on Learning Problems in Mathematics (1997 only), Journal for Research in Mathematics, Journal of Applied Behavior Analysis (1998 only), Journal of Experimental Education (1998 only), Journal of Instructional Psychology, Journal of Learning Disabilities, Journal of Special Education Technology (1997 only) Learning Disabilities Research \& Practice, Mathematics Teaching (1998 only), Psychological Reports, Psychology in the Schools, School Psychology Review, School Science and Mathematics, Teaching Exceptional Children, and the Journal of Special Education.

As noted above, several journals received only the 1997 manual search. The 1998 issues of these journals were not available at the time of this search. Also, several journals received only the 1998 manual search. The 1997 issues of these journals were currently in the library binding process and, therefore, unavailable at the time of this search.

The last step in the search process involved an ancestral search through the reference lists of the obtained articles. These search procedures yielded one conference paper, six dissertations, and 44 journal articles with studies that met the criteria for selection. Three of the journal articles contained two studies. 


\section{Selection Criteria}

Studies were included in this review if: (a) the procedures and data-based results were published between 1988 and 1998 , (b) the subjects were elementary or secondary students with identified learning disabilities, (c) the study included at least two subjects, (d) the purpose of the study was to examine the effectiveness of an instructional intervention on students' math performance. Studies were excluded from this review if: (a) the subjects were identified as having a disability other than learning disabilities (e.g., remedial, atrisk, mildly handicapped), (b) the subjects with learning disabilities were included in experimental groups along with other types of students (e.g., students with mental retardation, students with mild disabilities) and their performance was measured as a group, (c) the purpose of the study was to identify characteristics of students with math disabilities, (d) the purpose of the study was to assess the math abilities of students with learning disabilities without implementing an instructional intervention.

Several studies located during the search process included a mixed group of students (e.g., students with learning disabilities, students with mental retardation, students who were at-risk). If student performance data were reported individually, the study was included in this review. Only data related to students with learning disabilities are discussed here.

\section{Overview of the Included Studies}

As a result of the search and selection procedure, 54 studies were identified. These studies were published between 1988 and 1997 and included 1,034 students with learning disabilities. The median number of subjects involved in these studies was eight. Of the 54 studies, 34 took place in elementary schools, 2 took place in the lower division of an independent school, 8 took place in middle / junior high schools, 5 took place in high schools, 3 took place in elementary and middle schools, and 2 took place in junior high and high schools. Single-subject designs were used in 29 (54\%) of the studies, group comparison designs were used in $18(33 \%)$ of the studies, quasi-experimental pre-post designs were used in $3(5 \%)$ of the studies, single subject and group comparison designs were used in $1(2 \%)$ study, the qualitative case study method was used in $1(2 \%)$ study, and the design was not identified in $2(4 \%)$ studies. The most frequently used dependent measure was criterion-referenced tests (51 studies, or $94 \%$ ); only 3 studies (6\%) used standardized measures.

\section{COMPUTATION AND RELATED INSTRUCTION}

Many students with learning disabilities have difficulty computing basic facts in addition, subtraction, multiplication, and division, especially when compared to their nondisabled peers. Students who achieve accuracy and fluency in computation receive higher grades in math, feel better about instructing, and perform better on higher-level problemsolving skills. Zentall and Ferkis (1993) found that computational speed was a significant predictor of word-problem performance. Many of the studies in this review focused on improving students' performance in math computation, as shown in Table 1.

\section{Use of Constant Time Delay}

Koscinski and Gast (1993b) examined constant time delay for teaching multiplication facts to elementary school students with learning disabilities. A multiple-probe design was used with five students. Each student took a pretest to establish which facts would be taught, and several fiveproblem sets of facts were developed for each student. During the intervention, the student was directed to answer the problem without guessing. If the student did not know the answer, the investigator supplied the answer after waiting 4 seconds. Then the student was instructed to read the problem again and give the correct answer. Students who did not wait for the answer were reminded to wait for the correct answer. The students achieved $100 \%$ accuracy on multiplication facts using the constant time-delay procedure. They reached this mastery level in less than 1 hour per set. Students were able to generalize their responses from vertical problem presentation to horizontal presentation as well as from verbal to written responses.

In a similar study, Koscinski and Gast (1993a) used a computer software program to deliver prompts. Six elementary students with learning disabilities participated in this single-subject, multiple-probe study. Before the intervention began, the teacher presented multiplication flashcards to determine which facts the subjects did not know. These unknown facts were entered into each student's computer file to be used in the intervention.

The computer software was programmed to present unknown multiplication facts horizontally one at a time. Students were required to look at the multiplication problem on the screen, enter each factor as the cursor blinked, and then to solve the problem if they knew the answer. The computer supplied the correct solution after 5 seconds if the student failed to respond or entered the wrong answer. Mastery 
TABLE 1

Computation Studies

\begin{tabular}{|c|c|c|c|c|c|c|}
\hline Intervention & Citation & Subjects & Setting & Design & $\begin{array}{l}\text { Dependent } \\
\text { Measure }\end{array}$ & Results \\
\hline \multirow[t]{4}{*}{$\begin{array}{l}\text { Constant } \\
\text { Time Delay }\end{array}$} & $\begin{array}{l}\text { Koscinski \& Gast, } \\
\text { 1993a }\end{array}$ & 6 & $\begin{array}{l}\text { Elementary self- } \\
\text { contained class }\end{array}$ & $\begin{array}{l}\text { Multiple } \\
\text { probe }\end{array}$ & $\begin{array}{l}\text { Criterion- } \\
\text { referenced }\end{array}$ & $\begin{array}{l}\text { Software using } 5 \text {-second delay was } \\
\text { effective for acquisition of } \\
\text { multiplication }\end{array}$ \\
\hline & $\begin{array}{l}\text { Koscinski \& Gast, } \\
\text { 1993b }\end{array}$ & 5 & $\begin{array}{l}\text { Elementary self- } \\
\text { contained class }\end{array}$ & $\begin{array}{l}\text { Multiple } \\
\text { probe }\end{array}$ & $\begin{array}{l}\text { Criterion- } \\
\text { referenced }\end{array}$ & $\begin{array}{l}\text { 4-second delay was effective for } \\
\text { acquisition and generalization of } \\
\text { multiplication }\end{array}$ \\
\hline & $\begin{array}{l}\text { Morton \& Flynn, } \\
1997\end{array}$ & 4 & $\begin{array}{l}\text { Elementary } \\
\text { research-only } \\
\text { class }\end{array}$ & $\begin{array}{l}\text { Multi- } \\
\text { element } \\
\text { baseline }\end{array}$ & $\begin{array}{l}\text { Criterion- } \\
\text { referenced }\end{array}$ & $\begin{array}{l}\text { Constant time delay and prompt } \\
\text { fading were effective in teaching } \\
\text { multiplication facts }\end{array}$ \\
\hline & $\begin{array}{l}\text { Williams \& Collins, } \\
1994\end{array}$ & 4 & $\begin{array}{l}\text { Special elementary } \\
\text { school for learning } \\
\text { disabilities }\end{array}$ & $\begin{array}{l}\text { Multiple } \\
\text { probe }\end{array}$ & $\begin{array}{l}\text { Criterion- } \\
\text { referenced }\end{array}$ & $\begin{array}{l}\text { Self-selection of material prompts } \\
\text { was more effective than teacher } \\
\text { selection }\end{array}$ \\
\hline \multirow[t]{3}{*}{$\begin{array}{l}\text { Direct } \\
\text { Instruction }\end{array}$} & $\begin{array}{l}\text { Hastings, Raymond, } \\
\text { \& McLaughlin, } 1989\end{array}$ & 2 & $\begin{array}{l}\text { High school } \\
\text { resource room }\end{array}$ & $\begin{array}{l}\text { Multiple } \\
\text { baseline }\end{array}$ & $\begin{array}{l}\text { Criterion- } \\
\text { referenced }\end{array}$ & $\begin{array}{l}\text { Rate and accuracy improved } \\
\text { after direct instruction }\end{array}$ \\
\hline & Rivera \& Smith, 1988 & 8 & $\begin{array}{l}\text { Middle school } \\
\text { resource room }\end{array}$ & $\begin{array}{l}\text { Multiple } \\
\text { baseline }\end{array}$ & $\begin{array}{l}\text { Criterion- } \\
\text { referenced }\end{array}$ & $\begin{array}{l}\text { Demonstration-imitation-keywords } \\
\text { intervention was effective in teaching } \\
\text { division }\end{array}$ \\
\hline & $\begin{array}{l}\text { Van Houten \& Rolider, } \\
1990\end{array}$ & 3 & $\begin{array}{l}\text { Private clinic and } \\
\text { elementary resource } \\
\text { room }\end{array}$ & $\begin{array}{l}\text { Multiple } \\
\text { baseline }\end{array}$ & $\begin{array}{l}\text { Criterion- } \\
\text { referenced }\end{array}$ & $\begin{array}{l}\text { Color coding improved learning of } \\
\text { number names }\end{array}$ \\
\hline \multirow[t]{3}{*}{$\begin{array}{l}\text { Goal } \\
\text { Structure }\end{array}$} & $\begin{array}{l}\text { Fuchs, Bahr, \& Rieth, } \\
1989\end{array}$ & 20 & $\begin{array}{l}\text { High school self- } \\
\text { contained class }\end{array}$ & $\begin{array}{l}\text { Group } \\
\text { comparison }\end{array}$ & $\begin{array}{l}\text { Criterion- } \\
\text { referenced }\end{array}$ & $\begin{array}{l}\text { Self-selection of goals more effective } \\
\text { than assigned goals }\end{array}$ \\
\hline & $\begin{array}{l}\text { Fuchs, Fuchs, } \\
\text { Hamlett, \& Whinnery, } \\
1991\end{array}$ & 36 & $\begin{array}{l}\text { Elementary and } \\
\text { middle school } \\
\text { classes }\end{array}$ & $\begin{array}{l}\text { Group } \\
\text { comparison }\end{array}$ & $\begin{array}{l}\text { Standardized } \\
\text { test }\end{array}$ & $\begin{array}{l}\text { Goal-line group was more stable in } \\
\text { math performance than control group } \\
\text { no difference in level or rate of } \\
\text { performance }\end{array}$ \\
\hline & $\begin{array}{l}\text { Whinnery \& Fuchs, } \\
1993\end{array}$ & 40 & $\begin{array}{l}\text { Elementary and } \\
\text { middle school } \\
\text { resource rooms }\end{array}$ & $\begin{array}{l}\text { Group } \\
\text { comparison }\end{array}$ & $\begin{array}{l}\text { Criterion- } \\
\text { referenced }\end{array}$ & $\begin{array}{l}\text { No difference in goal strategy groups; } \\
\text { test-taking group did better than } \\
\text { control students }\end{array}$ \\
\hline $\begin{array}{l}\text { Lecture- } \\
\text { Pause }\end{array}$ & $\begin{array}{l}\text { Hawkins, Brady, } \\
\text { Hamilton, Williams, \& } \\
\text { Taylor, } 1994\end{array}$ & 6 & $\begin{array}{l}\text { High school special } \\
\text { education class }\end{array}$ & $\begin{array}{l}\text { Simulta- } \\
\text { neous } \\
\text { treatment }\end{array}$ & $\begin{array}{l}\text { Criterion- } \\
\text { referenced }\end{array}$ & $\begin{array}{l}\text { Lecture-pause was effective for both } \\
\text { independent and peer-guided pauses }\end{array}$ \\
\hline \multirow[t]{4}{*}{$\begin{array}{l}\text { Manipulative } \\
\text { Devices and } \\
\text { Drawings }\end{array}$} & Funkhouser, 1995 & 12 & $\begin{array}{l}\text { Elementary general } \\
\text { education classroom }\end{array}$ & $\begin{array}{l}\text { Case study } \\
\text { of intact } \\
\text { group }\end{array}$ & $\begin{array}{l}\text { Criterion- } \\
\text { referenced }\end{array}$ & $\begin{array}{l}\text { All students were successful in } \\
\text { subitizing and computation }\end{array}$ \\
\hline & $\begin{array}{l}\text { Harris, Miller, \& } \\
\text { Mercer, } 1995\end{array}$ & 12 & $\begin{array}{l}\text { Elementary general } \\
\text { education classroom }\end{array}$ & $\begin{array}{l}\text { Multiple } \\
\text { baseline }\end{array}$ & $\begin{array}{l}\text { Criterion- } \\
\text { referenced }\end{array}$ & $\begin{array}{l}\text { All subjects improved from pre-to } \\
\text { posttest after CSA }\end{array}$ \\
\hline & Miller \& Mercer, 1993b & 5 & $\begin{array}{l}\text { Elementary } \\
\text { resource room }\end{array}$ & $\begin{array}{l}\text { Multiple } \\
\text { baseline }\end{array}$ & $\begin{array}{l}\text { Criterion- } \\
\text { referenced }\end{array}$ & $\begin{array}{l}\text { CSA was effective with basic facts; } \\
\text { crossover at } \mathrm{C} \text { or } \mathrm{S} \text { phase }\end{array}$ \\
\hline & $\begin{array}{l}\text { Peterson, Mercer, \& } \\
\text { O'Shea, } 1988\end{array}$ & 24 & $\begin{array}{l}\text { Elementary and } \\
\text { middle school } \\
\text { self-contained and }\end{array}$ & $\begin{array}{l}\text { Group } \\
\text { comparison }\end{array}$ & $\begin{array}{l}\text { Criterion- } \\
\text { referenced }\end{array}$ & $\begin{array}{l}\text { CSA was more effective than } \\
\text { abstract-only method }\end{array}$ \\
\hline
\end{tabular}


TABLE 1 (continued)

\begin{tabular}{|c|c|c|c|c|c|c|}
\hline Intervention & Citation & Subjects & Setting & Design & $\begin{array}{l}\text { Dependent } \\
\text { Measure }\end{array}$ & Results \\
\hline \multirow[t]{6}{*}{$\begin{array}{l}\text { Self- } \\
\text { Regulation }\end{array}$} & Brown \& Frank, 1990 & 6 & $\begin{array}{l}\text { resource classes } \\
\text { Elementary } \\
\text { resource room }\end{array}$ & $\begin{array}{l}\text { Multiple } \\
\text { baseline }\end{array}$ & $\begin{array}{l}\text { Criterion- } \\
\text { referenced }\end{array}$ & $\begin{array}{l}\text { Two studies: addition and subtraction } \\
\text { improved and results were maintained }\end{array}$ \\
\hline & Bryan \& Bryan, 1991 & 18 & $\begin{array}{l}\text { Junior high and high } \\
\text { school special } \\
\text { education classes }\end{array}$ & $\begin{array}{l}\text { Group } \\
\text { comparison }\end{array}$ & $\begin{array}{l}\text { Criterion- } \\
\text { referenced }\end{array}$ & $\begin{array}{l}\text { Positive mood enhanced math } \\
\text { accuracy }\end{array}$ \\
\hline & $\begin{array}{l}\text { Dunlap \& Dunlap, } \\
1989\end{array}$ & 3 & $\begin{array}{l}\text { Elementary } \\
\text { resource room }\end{array}$ & $\begin{array}{l}\text { Multiple } \\
\text { baseline }\end{array}$ & $\begin{array}{l}\text { Criterion- } \\
\text { referenced }\end{array}$ & $\begin{array}{l}\text { Number of problems solved correctly } \\
\text { increased with self-monitoring } \\
\text { package }\end{array}$ \\
\hline & Holmes, 1991 & 10 & $\begin{array}{l}\text { Elementary } \\
\text { resource room }\end{array}$ & $\begin{array}{l}\text { Group } \\
\text { comparison }\end{array}$ & $\begin{array}{l}\text { Standardized } \\
\text { test }\end{array}$ & $\begin{array}{l}\text { Verbal self-instruction strategy } \\
\text { increased accuracy }\end{array}$ \\
\hline & Ross \& Braden, 1991 & 94 & $\begin{array}{l}\text { Elementary } \\
\text { resource room }\end{array}$ & $\begin{array}{l}\text { Group } \\
\text { comparison }\end{array}$ & $\begin{array}{l}\text { Standardized } \\
\text { test }\end{array}$ & $\begin{array}{l}\text { Cognitive behavior management and } \\
\text { token reinforcement group did better } \\
\text { than control group }\end{array}$ \\
\hline & $\begin{array}{l}\text { Wood, Rosenberg, \& } \\
\text { Carran, } 1993\end{array}$ & 9 & $\begin{array}{l}\text { Elementary therapy } \\
\text { rooms adjacent to } \\
\text { classroom }\end{array}$ & $\begin{array}{l}\text { Multiple } \\
\text { probe }\end{array}$ & $\begin{array}{l}\text { Criterion- } \\
\text { referenced }\end{array}$ & $\begin{array}{l}\text { Students improved in accuracy, } \\
\text { number of problems attempted, and } \\
\text { time on task }\end{array}$ \\
\hline $\begin{array}{l}\text { Strategy } \\
\text { Instruction }\end{array}$ & $\begin{array}{l}\text { Naglieri \& Gottling, } \\
1995\end{array}$ & 4 & $\begin{array}{l}\text { Lower division of } \\
\text { independent school } \\
\text { for students with } \\
\text { learning problems }\end{array}$ & $\begin{array}{l}\text { Not } \\
\text { identified }\end{array}$ & $\begin{array}{l}\text { Criterion- } \\
\text { referenced }\end{array}$ & $\begin{array}{l}\text { Strategy helped low planners add and } \\
\text { multiply; no improvement in } \\
\text { multiplication for average planners }\end{array}$ \\
\hline
\end{tabular}

criterion was set at $100 \%$ correct for two sessions. To facilitate maintenance and generalization, each student completed an untimed review fact sheet of 15 problems. As new facts were learned, they were added to the review pool to be added to worksheets.

Generalization to a written format was assessed using worksheets that presented the problems vertically or reversed the factors. Verbal generalization was assessed using teacher-presented flashcards. The data revealed that all subjects learned the targeted multiplication facts and made few errors on the probes. The researchers noted that as students became familiar with the intervention, they required less time to achieve mastery.

In their 1994 study, Williams and Collins compared the efficacy of student-selected material prompts to teacherselected material prompts in the constant time-delay procedure. Four boys with learning disabilities ranging in age from 9 years 6 months to 13 years 10 months were selected to participate in their single-subject, multiple-probe study. Each student worked with 10 multiplication facts per session with three trials per session. Multiplication facts were printed on flashcards. The first two trials per fact were 
presented at a 0 -second delay, and subsequent trials were presented at a 5-second delay. Three material prompts were used in this study: 120 poker chips of three colors, a computer-printed timeline with numbers from 1 to 100 , and students' fingers. If a student gave an incorrect answer, he was directed to compute the problem using one of the three material prompts.

Teacher selection of prompts was counterbalanced with student selection of prompts. All students learned the targeted multiplication facts soon after the intervention began, and all students maintained fluency after the prompts were faded. Student-selection of prompts was more effective and efficient than teacher-selection for all students; students tended to select the prompts that worked most effectively for them.

Morton and Flynn (1997) compared the efficacy of two prompting techniques - constant time delay and prompt fading - in teaching multiplication facts to students with learning disabilities. Three third-grade boys and one fourth-grade boy were selected to participate in their single-subject multielement baseline study. Precision teaching measurement also was used in this investigation. For the constant time delay procedure, math facts without answers were written on cards. For the prompt fading procedure, math facts with answers of varying intensity were written on cards. A 4-second interval was used in the constant time delay phase.

The procedure was similar to those outlined in the preceding studies. During the prompt fading procedure, the intensity of the answer decreased over time. The first trial had cards with the answer printed at $100 \%$ intensity, and the second, third, and fourth trials had answers printed at $75 \%$, $50 \%$, and $25 \%$, respectively. Although one method was not shown to be superior to the other, both procedures were effective for acquiring multiplication facts. The researchers cautioned that the experiment's alternating design may have contributed to a carryover effect from one procedure to the other, confounding the results.

\section{Use of Manipulative Devices and Drawings}

Peterson, Mercer, and O'Shea (1988) compared the effectiveness of two teaching methods-concrete-semiconcrete-abstract (CSA) and abstract-only-in teaching place value to students with learning disabilities. The 24 elementary and middle-school students with learning disabilities were divided into an experimental and a control group for this study. Each group of students received instruction in identifying place value through carefully scripted lessons. The only difference between the two groups was that the experimental group received three lessons using manipulative devices (popsicle sticks), three lessons using semiconcrete instruction (drawings), and three lessons at the abstract level (numbers only). The control group received all nine lessons at the abstract level. Statistically significant differences, favoring the experimental group, were noted for instructional method on three acquisition measures: posttest, maintenance, and retention. No group differences were found in generalizing to untaught place value skills.

Miller and Mercer (1993b) examined the effectiveness of the CSA procedure in teaching addition facts and coin sums and determined how many lessons were needed at each level before the students were able to transfer skills to abstract problems. Five students identified with learning disabilities participated in the multiple baseline-across-subjects investigation. During the baseline phase, daily 1-minute probes were administered with no teacher feedback. The treatment phase consisted of 20-minute scripted lessons including an advance organizer, demonstration and modeling, guided practice, and independent practice. Each lesson was followed by a 1-minute assessment probe at the abstract level. Students progressed to the next lesson if they achieved $80 \%$ accuracy on the independent practice problems.

All students in this investigation reached the $80 \%$ criterion on their first attempt. Results indicated that the CSA sequence was effective for acquiring math skills after five 20-minute lessons at each stage. During the concrete stage, three of the students with learning disabilities answered more problems correctly than incorrectly on the 1-minute probes, indicating a "crossover effect," or ability to generalize from concrete instruction to abstract problems. The other two students achieved the crossover effect during semiconcrete instruction. Thus, for some students, fewer lessons at the concrete stage may be effective, whereas other students may need five at each stage to achieve mastery.

Harris, Miller, and Mercer (1995) explored the use of the concrete-representational-abstract (CRA) procedure for teaching multiplication facts to students with learning disabilities in general education settings. Twelve second-grade students with learning disabilities, along with 99 students without disabilities and one student with an emotional disability, participated in this single-subject, multiple baselineacross-classrooms investigation. Six general education teachers taught multiplication to their intact classes using scripted lessons that progressed through the CRA sequence. Students also were taught a mnemonic device to facilitate the transition from representational to abstract instruction. All 12 students with learning disabilities improved from 
pretest to posttest, with the extent of improvement ranging from 25 to 85 percentage points.

Funkhouser (1995) investigated the use of manipulative devices to teach basic number concepts to 12 kindergarten and first-grade children with learning disabilities. In this intervention, children were taught to glue jellybeans within five-cell frames (vertical rectangle divided into five equalsized boxes) to represent numbers. For the first 2 weeks, students built number frames for the numbers 0 through 5 . During the third week, students explored combinations of number frames that resulted in sums 0 through 5 , and in the final week, the "+" symbol was introduced. At the end of the 4-week intervention, all 12 students achieved over $90 \%$ mastery in recognizing and matching numbers from 0 through 5 and in adding sums to 5 .

\section{Use of Direct Instruction}

Hastings, Raymond, and McLaughlin (1989) examined the use of direct instruction to teach two secondary students with learning disabilities to count money. A multiple baseline-across-students design was used to determine the effects of the intervention. Students were given bags of money and were taught to count the coins and bills efficiently with a sequential series of steps over 20 intervention sessions. As part of the training, students were taught to use a tens number line to reduce errors in counting dimes and to assist in grouping nickels and quarters. Periodic probes were conducted to determine if the intervention was producing fast, accurate change counting. For both students, the intervention produced a decrease in the amount of time needed to count the 10 pieces of money, and accuracy remained at or near $100 \%$.

Rivera and Smith (1988) used a demonstration-imitationkeyword intervention to teach long division to eight middleschool students with learning disabilities. In this procedure, the teacher demonstrated a problem while verbalizing keywords, and the students imitated the process. Then the students completed a worksheet that displayed the demonstrated problem as a reference. The teacher circulated among the students as they completed their worksheets, reminding them of the keywords as necessary. All students achieved criterion ( $100 \%$ correct in two of three days) in division problems with and without remainders. The amount of time to criterion varied from 2 to 9 days.

Van Houten and Rolider (1990) examined the effects of matching a numeral with a specific color to teach number names. Three boys, aged 6,7 , and 8 participated in this multiple baseline study. During the baseline phase, each boy was asked to identify numerals written with black ink on index cards. Correct responses were praised, and error responses were corrected. During the intervention phase, a numeral was printed on an index card in a specific color, and the boys were taught to identify the color and number (e.g., "green three"). When a color and number were identified correctly for five consecutive sessions, the color was dropped and the numeral was again written in black ink. The color mediation technique led to an immediate increase in numeral-naming accuracy for each of the boys. For two of the boys, follow-up checks were conducted after 1,2,3, and 4 months. Both of these boys maintained $100 \%$ accuracy after 4 months. Follow-up data were not collected for the third boy because the school year ended.

\section{Use of Strategy Instruction}

Van Houten (1993) compared two methods of teaching subtraction facts to students with learning disabilities. Four elementary students participated in this single-subject, alternating-treatment design investigation. Each student was taught two sets of seven subtraction facts each-one set through traditional rote learning and the other set using a rule strategy. In the rote-learning treatment, students were presented with subtraction facts written on flashcards. In all subtraction problems, either 7 or 9 was the minuend. The researcher shuffled the cards, and the students responded verbally to each problem. If a student answered incorrectly, the researcher supplied the answer and repeated the question. In the alternating treatment, the procedure was the same except that students were taught rules for answering the problems. When subtracting 7 from a teen number, students were told to add 3 to the digit above the 7. A similar rule was taught for subtracting 9 from a teen number. Using the rule method, students reached criterion ( $90 \%$ accuracy) in 1 to 3 days. Using the rote method, students reached criterion in 5 to 6 days. A follow-up session, 1 month later, revealed that all students remained above criterion.

Naglieri and Gottling (1995) hypothesized that students who have difficulty in math are poor planners and that they would benefit from strategy instruction that facilitates planning. Four elementary school boys with learning disabilities were screened using a cognitive assessment. Two boys scored low in planning, and the other two boys had average planning scores. Baseline measures obtained during three baseline sessions indicated that the two boys who were poor in planning answered fewer problems correctly. All four boys participated in seven intervention sessions. The sessions consisted of 10 minutes of independent worksheet 
practice, 5 minutes of teacher-facilitated self-reflection, and another 10 minutes of independent worksheet practice. During the 5 minutes of self-reflection, the teacher asked questions such as, "What did you notice about how you did your work?" and encouraged the students to talk about the strategies they had used.

Following the intervention all four boys improved their scores in addition. The boys who had low planning scores improved $115 \%$, and the boys with average planning scores improved $100 \%$. In multiplication, the two boys with low planning improved their scores $500 \%$ and the two boys with average planning had about the same scores as baseline.

In a follow-up study, Naglieri and Gottling (1997) replicated and extended the preceding investigation in a group setting. Twelve students with learning disabilities participated in the 7 baseline and 21 intervention sessions. During baseline and intervention sessions, each student attempted 54 mathematical problems on worksheets for a 10-minute period. A 10-minute class discussion followed. During baseline, the discussion was unrelated to the worksheets. During the intervention sessions, the teacher asked questions such as, "Let's talk about how you did the work today." The teacher's specific objective during the intervention was to encourage students to verbalize and reflect upon their work strategies. The class discussion was followed by a final 10minute work session.

Results indicated that students with low planning scores improved more than students with high planning scores, although all students in this study improved their scores over baseline. Interestingly, while students with low planning scores improved consistently over the 21 sessions, those with high planning scores improved much more during sessions 15 through 21.

\section{Use of Lecture-Pause}

Hawkins, Brady, Hamilton, Williams, and Taylor (1994) compared the effects of two types of instructional pauses in mathematics lectures. Specifically, the investigators alternated peer-guided pauses and independent pauses. Seven high school students with learning disabilities participated in this study, although data were presented for only six subjects because one student left the school district. During all sessions, the teacher reviewed material for 2 minutes, lectured for 4 minutes, paused for 5 minutes, lectured for 4 minutes, and paused for an additional 5 minutes. In the independent-pause condition, students practiced the mathematics skill covered in the lecture for 4 minutes and checked their answers for 1 minute. In the peer-guided condition, students worked in dyads to practice the mathematics skill for 4 minutes and checked answers for 1 minute.

All six students increased their accuracy in addition, subtraction, and multiplication from pretest to posttest. A significant decrease in error rate was detected in addition but not in subtraction or multiplication. Regarding the efficacy of the treatment conditions, results were mixed. Some students had better results with peer-guided pause, and others benefited from the independent-pause condition. The authors concluded that incorporating an instructional pause that allowed students to practice and receive feedback was more important than the type of pause employed.

\section{Use of Goal Structure}

Fuchs, Bahr, and Rieth (1989) examined the effects of goal-setting and contingent rewards upon the computation performance of students with learning disabilities. Twenty high-school students were assigned randomly to four treatment groups: assigned goal/noncontingent gameplay, assigned goal/contingent gameplay, self-selected goal/ noncontingent gameplay, and self-selected goal/contingent gameplay. A computer software program was used to generate math drill-and-practice problems and to monitor student progress in four 1-minute practice periods.

Students in the assigned goal groups had a goal of 15 correct digits per minute for the 4-minute session, and those in the self-selected goal condition could choose among goals of 10,15 , or 20 correct digits per minute. Students in the noncontingent gameplay group were allowed to play a video game, Donkey, following each 1-minute practice period whether they had or had not met the goal. Those in the contingent gameplay group had access to the game only if their goals had been met or exceeded. The intervention consisted of one 5-minute keyboarding session, one 8-minute pretest, three 4-minute computerized drill-and-practice sessions with appropriate goals and contingency conditions, one 8minute midtest, three additional computerized drill-andpractice sessions as detailed above, and one 8-minute posttest.

Statistically significant differences were found between the two goal conditions favoring the self-selected goal groups. Further analysis showed that statistically significant differences were found between the goal groups from pretest to midtest but not from midtest to posttest. Interestingly, data indicated that the average goal chosen in the selfselection condition was 15 digits per minute, the same goal as in the assigned goal condition. No differences were found between the gameplay conditions. 
Fuchs, Fuchs, Hamlett, and Whinnery (1991) examined the effects of goal-line feedback on math achievement using curriculum-based measurement (CBM). Rather than assessing a single skill, CBM incorporates a series of assessments throughout the school year to determine which curriculum objectives have been met and to evaluate overall program effectiveness. Nineteen teachers selected two of their students with learning disabilities to participate in the study. Of the 38 selected, 36 students completed the intervention. One student of each teacher was randomly assigned to the goal-line condition, and the other was assigned to the no goal-line condition. Three dependent variables were measured: rate of improvement on the CBM tests, level of performance, and stability of performance. CBM assessments were conducted periodically during the academic year. Each student in the goal-line group was shown a graph with his individual scores and the teacher's goal superimposed, and students in the no goal-line group saw graphs of their individual scores without a goal-line. No statistically significant differences were found between the groups in level of performance or rate of improvement. Students in the goal-line group, however, had significantly more stable math performance than students in the no goalline group.

In a subsequent study, Whinnery and Fuchs (1993) examined the effects of combining CBM and goal-lines with a test-taking strategy. Twenty-four teachers of students with learning disabilities selected two students each to participate, although only 40 students completed the study. Each of the 24 teachers was randomly assigned to the goal-line condition or the no goal-line condition. Then one of the two students was selected for the test-taking strategy and the other student did not receive the testtaking strategy.

The goal-line procedure was similar to the one outlined in the Fuchs, Fuchs, Hamlett, and Whinnery (1991) study. Students in the test-taking strategy group were shown their most recently completed test with correct items circled. Then, for the current test, they were taught to immediately complete items of which they were sure, circle items of which they were less sure, and skip unknown items. After they had completed all the known items, the students returned to the circled items (of which they were less sure) before attempting the unknown problems. A significant difference was found in math achievement scores favoring the test-taking group. Like the Fuchs et al. (1991) study, no significant differences were found between the goal-line and no goal-line groups for math achievement.

\section{Use of Self-Regulation}

Dunlap and Dunlap (1989) investigated the effectiveness of a self-monitoring intervention on three elementary students with learning disabilities who had difficulty solving subtraction problems. The researchers used a multiple baseline-across-students design with a two-phase baseline. The first baseline consisted of traditional didactic instruction. The teacher verbally explained the procedure, students completed worksheets, and appropriate verbal praise or feedback was given upon completion of the worksheets. During the second baseline phase, the same procedure was followed, but incentive points were given for correct responses. (The points were used in a classroom reinforcement system).

The self-monitoring intervention was introduced after these two baseline phases. Individual self-monitoring checklists were developed for each student based on his error patterns in the two baseline phases. The checklists consisted of reminder statements such as: I copied the problem correctly, I regrouped when I needed to (top number is bigger than bottom), I borrowed correctly (number crossed out is one bigger), I subtracted all the numbers, and I subtracted correctly. During this phase the students used the checklists as they completed their worksheets. Students recorded a plus or a minus next to each reminder to indicate whether they had or had not performed that step. Students were awarded one point each for problems solved correctly and an additional point for the problem if they had followed all of the steps on the checklist.

All three students showed immediate improvement in solving subtraction problems correctly when the intervention was introduced. Follow-up data revealed that students maintained the improved accuracy levels.

Brown and Frank (1990) conducted two investigations combining self-monitoring and mnemonic devices to improve computation skills of students with learning disabilities. Three elementary students who had experienced difficulty in solving subtraction problems with regrouping participated in the first experiment. A multiple baselineacross-subjects design was used to assess the intervention. During each baseline session, students were given a subtraction worksheet and told to complete it to the best of their ability.

For the intervention phase, each student was individually taught the "4 B's" strategy (Begin, Bigger, Borrow, and Basic Facts) through teacher modeling and demonstration. Once students could say the strategy from memory, they were given subtraction worksheets with strategy steps listed 
next to the problems. These worksheets were used three times a week. If students forgot to use the checklist, the teacher reminded them to do so. The accuracy of all three students improved following the intervention and was maintained in follow-up probes.

In the second investigation, the researchers again used a multiple baseline-across-subjects design involving three elementary students with learning disabilities. During baseline, students were given tests with no corrective feedback. Although a different mnemonic device was used, the intervention was similar to that used in the first study. All students achieved criterion ( $90 \%$ accuracy) soon after the intervention was introduced and maintained those results in followup sessions.

Holmes (1991) examined the effectiveness of verbal selfinstruction (VSI) delivered in a group setting compared to an individual setting. Ten elementary students with learning disabilities were randomly assigned to either the grouped or individualized treatment condition. First, all students were taught a learning strategy-Stop, Look, Listen, and Think. Then all subjects were taught to solve math problems while verbalizing specific steps. Five students were taught in a group and five received individualized instruction away from others.

VSI steps consisted of questions or statements such as: (a) What am I supposed to do?, (b) I have to concentrate and think about what I'm doing, (c) I'm supposed to solve the problem and go slowly and carefully, (d) If I make a mistake, I can erase it and go on, (e) Good, I did it!

Three weeks following the VSI intervention, maintenance sessions were conducted over four consecutive school days. Probes then were conducted to determine if any generalization had occurred from math to reading. Results indicated that all 10 subjects improved significantly in math performance. Statistical analysis revealed no significant difference between the two treatment groups, indicating that group instruction was just as effective as individualized instruction for these students. Generalization to reading performance could not be attributed to VSI.

Ross and Braden (1991) compared the effects of token reinforcement (TR), cognitive behavior management (CBM), and direct instruction on the math achievement scores of 94 elementary students with learning disabilities. Nine teachers and their classes were randomly assigned to either a CBM condition, a TR condition, or a direct instruction control condition. Students in the control group received the typical math program without any tangible reward system, although praise was used as a social reinforcer. Students in the TR condition received the same direct instruction as the control group but also were given a token for every correct math problem completed in class. The tokens were exchanged for items on a reinforcement menu, such as stickers or small toys.

Students in the CBM group were taught general selfinstruction rules for staying on task and specific self-instruction rules for solving math problems. Self-talk consisted of statements such as, "What kind of problem is this?" or "First I add the first column of numbers," or "Good. I've finished that problem. I need to keep on working." Teachers modeled the CBM procedure, instructed students to talk aloud as they worked problems, assisted and prompted students in the self-talk, and after the second week, told students to talk to themselves while working.

Results indicated that all three groups improved equally in 2-minute timings. On a standardized math achievement test, however, students in the CBM and TR groups performed significantly better than students in the control group. CBM and TR were equally effective on posttest and retention measures. In addition, CBM did not slow students' rates of responding.

Laird and Winton (1993) compared three self-instructional procedures for solving multi-step multiplication and division problems. Using an alternating treatment design study, seven adolescents were taught, through modeling and imitation, to verbalize self-instructions while solving math problems. Specifically, two checking procedures-endchecking and multi-checking-were compared to a nochecking procedure. The end-checking procedure required students to verbalize a self-instructional checking procedure after completing each problem. The multi-checking procedure required students to verbalize a self-instructional checking procedure after completing each step of the problem. During the no-checking procedure, students verbalized the steps for solving the problem but did not verbalize any checking procedure.

The multi-checking procedure was most effective, in terms of accuracy, for six of the seven students in this study. During a follow-up phase, students had the opportunity to select one of the three procedures. All seven selected the no-checking procedure, and consequently their accuracy decreased.

Wood, Rosenberg, and Carran (1993) used a multipleprobe design to examine the effects of tape-recorded selfinstruction cues on the addition and subtraction performance of nine elementary students with learning disabilities. The nine students were assigned to one of three treatment 
conditions: experimental condition, observer condition, or control condition. Students in the experimental condition and the observer condition attended two training sessions.

During the first training session, the students in the experimental condition watched the teacher demonstrate a 10 -step, self-instructional procedure for solving problems, wrote the 10 steps on a large chart, and practiced solving problems using the tape-recorded steps. The students in the observer condition watched the teacher demonstration but did not participate in the practice.

During the second training session, the teacher demonstrated the 10-step process again. The experimental students solved 20 problems using the steps. The observer students simply watched. Students in the control condition did not receive training and did not observe.

Neither the experimental nor the observer students were able to use the 10-step procedure, without taped cues, after the first training session. After the second training session, the experimental students were allowed to use the taperecorded cues. They demonstrated a dramatic increase in problem accuracy and maintained high performance levels as the tape-recorded cues were faded. The students in the observer and control conditions performed poorly throughout the study.

Bryan and Bryan (1991) explored a different aspect of self-regulation. They investigated the effects of positive mood on the math performance of 18 secondary students with learning disabilities. Students were randomly assigned to one of two treatment conditions: positive mood or notreatment control. Students in the positive mood condition were asked to close their eyes and remember happy events in their lives. After 45 seconds, they were asked to open their eyes and tell what they were thinking. Students in the control group were simply told that they would be completing math problems and were asked if they had done any math that day. Then all students were shown two pages of 50 addition and subtraction problems and asked how many problems they thought they might do. The students were then given 5 minutes to solve the problems. Students in the positive mood group had superior results in accuracy and in estimating how many problems they might do.

\section{COMPUTATION SYNTHESIS}

Fifteen of the 26 computation studies examined interventions designed to help students learn how to learn. These interventions included self-regulation, strategy instruction, and the use of manipulative devices and drawings (e. g.,
CSA sequence). In addition to improving computational skills, these interventions taught students how to attack math problems instead of passively waiting for teacher assistance. Opportunities for self-reflection and task monitoring were reflected in the strategy and self-regulation studies. Although different methods (verbalization, written checklists, or tape-recorders) were used in these studies, each included specific steps for students to follow when solving problems. The CSA interventions were used to promote conceptual understanding and provide students with a method for independently solving unknown facts.

The goal-structure studies indicated that students' performance improved when they set their own goals, even though the goals they set were almost identical to those of their teacher. Although students' achievement did not significantly increase, students' performance stabilized when they were shown a goal.

Other promising computation interventions included constant-time delay procedures, direct instruction (with and without color mediation), and lecture-pause. The constanttime delay and lecture-pause interventions seemingly were effective because they facilitated errorless learning and allowed students sufficient time for processing and retrieving information. Many of the studies reviewed used carefully scripted lessons such as those detailed in the direct instruction interventions. All of the computation interventions emphasized a high degree of proficiency before criterion was met-meaning skills practiced until mastery was achieved.

\section{PROBLEM-SOLVING INSTRUCTION}

Problem solving in mathematics has received more attention since the National Council of Teachers of Mathematics (1989) declared that it should be a top priority in math instruction. Although some ambiguity exists with regard to how problem solving is defined, most authorities still interpret problem solving within the context of word problems. Fortunately, an increase in problem-solving research is providing valuable information related to teaching these skills to students with learning disabilities. This research is summarized in Table 2.

\section{Use of Manipulative Devices and Drawings}

Miller and Mercer (1993a) conducted two validation studies to examine the effectiveness of using a graduated word problem sequence and the concrete-semiconcreteabstract teaching sequence while simultaneously teaching 
TABLE 2

Problem-Solving Studies

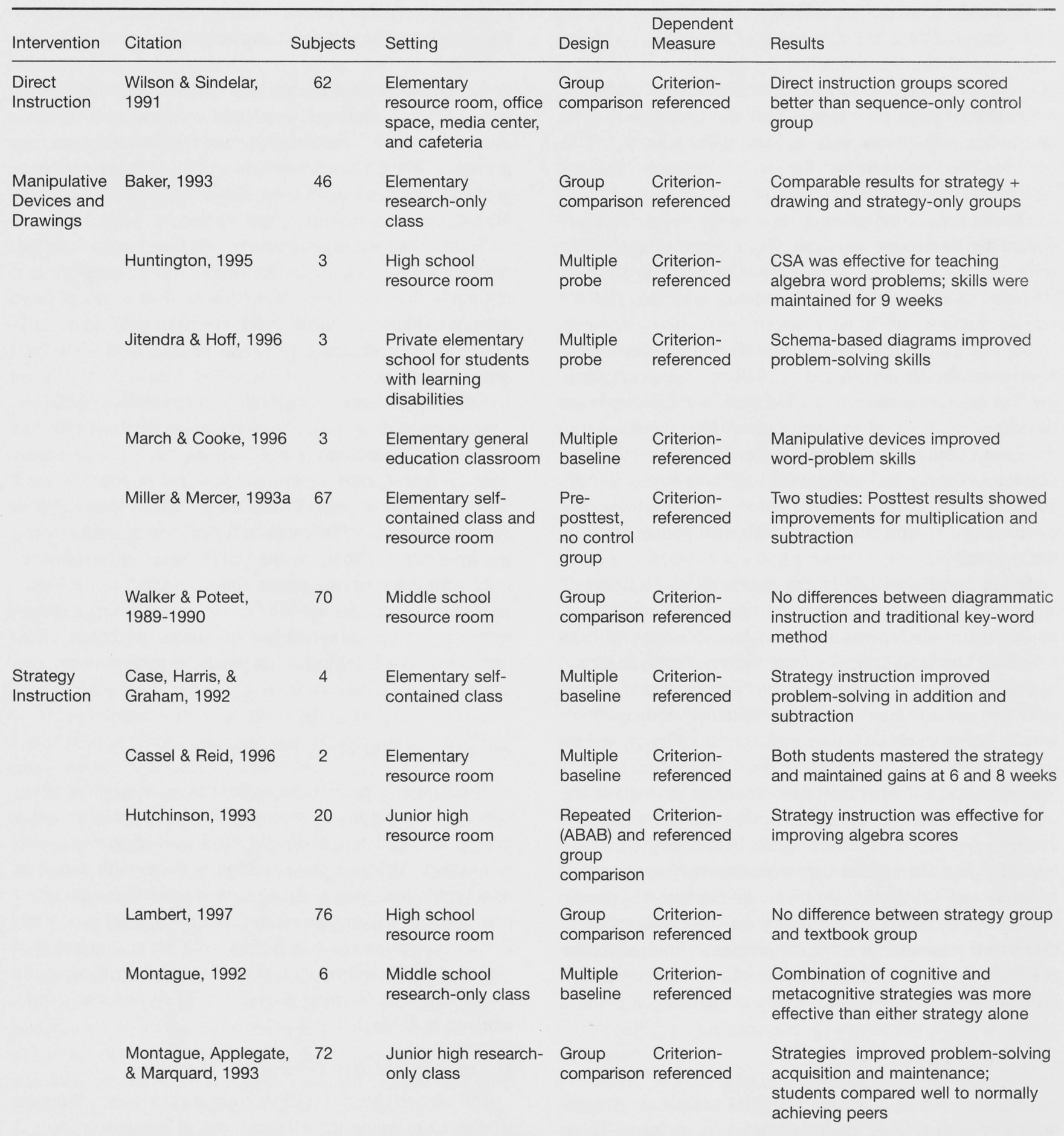


basic computation skills. In the first study, 54 elementary students with learning disabilities were taught multiplication facts using three concrete-level lessons involving manipulative devices, three semiconcrete-level lessons involving drawings and tallies, and between 10 and 15 abstract-level lessons depending on student absences. Also included in this instructional process were two mnemonic devices: one for computation and one for problem solving. The lessons were scripted and followed a four-step instructional process (advance organizer, demonstrate and model, guided practice, independent practice). The word problems gradually increased in difficulty from one lesson to the next.

Prior to these instructional lessons, the students were unable to solve any word problems. After the lessons, the overall posttest mean score was $84 \%$. An analysis of the different types of posttest problems resulted in a mean score of $97 \%$ for problems without extraneous information, $94 \%$ for problems with extraneous information, and $60 \%$ for createyour-own problems. Students needed additional practice to become proficient in making up their own word problems.

In the second study, 13 elementary students with learning disabilities were taught subtraction using the same instructional format (three concrete-level lessons, three semiconcrete-level lessons, one mnemonic device lesson, 15 abstract-level lessons, four-step instructional process, and graduated word problem sequence). Prior to these instructional lessons the students were unable to solve any word problems. After the lessons, the overall mean score was $92 \%$. Analysis of the various types of problems resulted in a mean score of $100 \%$ for problems without extraneous information, $86 \%$ for problems with extraneous information, and $91 \%$ for create-your-own word problems.

Huntington (1995) examined the effect of a concretesemiconcrete-abstract teaching sequence on the algebraic problem-solving performance of three high school students with learning disabilities. A multiple-probe design was used to investigate the three phases of instruction. During the concrete instructional phase, students represented problems with manipulative devices. During the semi-concrete instructional phase, students represented problems with manipulative devices and drew pictures of the representations. During the abstract instructional phase, students represented problems with manipulative devices, drew pictures of the representations, wrote algebraic equations, and solved the equations. Results of this study indicated that the CSA teaching sequence was effective. All three students reached $100 \%$ accuracy during three consecutive sessions. Moreover, these skills were maintained at 9 weeks.
Marsh and Cooke (1996) examined the effects of using manipulative devices (Cuisenaire rods) to teach students to identify the correct operation to use when solving math word problems. The subjects in their multiple-baseline study were three third-grade boys with learning disabilities. During the baseline phase of this study, the boys received group instruction in analyzing word problems using a verbal questioning technique. After one of the students read the word problem, the teacher asked questions such as, "What are we trying to find?" "Is there any information here that is not needed?" "Is this number needed?" and guided the students through the problem-solving process.

During the treatment phase of the study, the students read the word problem and the teacher verbally guided them in positioning their rods to demonstrate what the problem was asking. At the conclusion of each 20-minute lesson in this study, the students were given a 10 -item word problem probe to complete without using any manipulative devices. The performance of all three subjects improved after using manipulative devices. Specifically, they improved 58\%, $74 \%$, and $77 \%$ over baseline.

Walker and Poteet (1989-1990) compared the effectiveness of a diagrammatic method and a keyword method for solving math word problems. Their study involved 70 sixth-, seventh-, and eighth-grade students with learning disabilities. Students in the control group received traditional instruction in the keyword method (identifying words such as "altogether," "left," "in all," to help solve the problem). The students were taught to: (a) determine what was to be found based on a keyword method, (b) locate what information was given, (c) write a number sentence from the information given, and (d) find the answer for one-step story problems.

Students in the experimental group received diagrammatic instruction. These students were taught to (a) draw a diagrammatic representation of the problem, (b) write number sentences from the representation, and (c) solve the onestep story problems. After 17 days of instruction, the students were posttested on one- and two-step problems. There was no statistical difference between the two types of instruction; neither approach effectively increased performance from the pre- to posttest.

Baker (1993) investigated the effects of student-generated drawings on the ability of students with learning disabilities to solve two types of word problems-one involving multiplication or repeated addition and the other involving division or repeated subtraction. The 46 thirdthrough fifth-grade students were randomly assigned to the 
control and experimental groups. The control group received instruction in a four-step strategy: (a) read the problem, (b) restate the problem information, (c) identify the unknown information, (d) generate a problem solution. The experimental group received instruction in the same four-step strategy and, in addition, were encouraged to draw a pictorial representation of the problem prior to solving it. No significant differences were found between the two groups on either type of problem. Moreover, both groups demonstrated improvement from the pretest to the posttest.

Jitendra and Hoff (1996) examined the effectiveness of using schema-based diagrams for solving one-step addition and subtraction word problems. Using a multiple probeacross-students design, three elementary students with learning disabilities were taught to analyze word problems and map the critical elements onto preprepared schematic diagrams. The diagrams were designed to illustrate the relationships between the numbers in the word problems. Approximately eight scripted lessons were taught to each student. The lesson format involved teacher-led demonstration and modeling, along with frequent student exchanges to identify the critical elements of the problem and to map them on the appropriate schemata diagram.

Results indicated that all three students increased their percentage of correct word problem solutions after the schema-based diagram instruction. The subjects' mean scores prior to instruction were $20.3 \%, 31.3 \%$, and $26.6 \%$. After instruction their mean scores were $97.6 \%, 95 \%$, and $95.2 \%$, respectively. Maintenance probes 2 to 3 weeks after instruction ranged from $67 \%$ to $95.2 \%$.

\section{Use of Strategy Instruction}

Case, Harris, and Graham (1992) examined the effectiveness of a five-step strategy designed to help students comprehend and devise appropriate solutions for addition and subtraction word problems. The strategy was taught via oneto-one tutoring to four fifth- and sixth-grade students with learning disabilities. The five steps of the strategy were to (a) read the problem aloud, (b) look for important words and circle them, (c) draw pictures to help tell what is happening, (d) write down the math sentence, and (e) write down the answer. The strategy was taught using eight instructional stages: preskill development; conferencing; current performance level, metastrategy information, and commitment; discussion of the problem-solving strategy; modeling of the strategy and self-instructions; mastery of the strategy steps; collaborative practice of the strategy and self-instructions; independent performance; generalization and maintenance components.

On average, the students successfully completed $82 \%$ of the baseline addition word problems and $30 \%$ of the baseline subtraction word problems. After learning the strategy, these scores increased to $95 \%$ and $82 \%$, respectively. All four students generalized the use of the strategy from the tutoring sessions to their self-contained special education classroom. Maintenance probes administered 8 to 13 weeks after instruction revealed mixed results: Two students maintained instructional gains and two dropped in their performance. The authors recommended review sessions for the latter students.

Montague (1992) investigated the effects of cognitive and metacognitive strategy instruction on the problem-solving performance of six middle-school students with learning disabilities. The word problems used in this study were extracted from middle-school textbooks and included all four math operations and one-, two-, and three-step problems. The students in this multiple baseline study were taught a seven-step cognitive strategy and a three-step metacognitive strategy. The cognitive strategy steps were (a) read, (b) paraphrase, (c) visualize, (d) hypothesize, (e) estimate, (f) compute, and (g) check. The students had to memorize these seven cognitive processes. They also were taught three metacognitive activities associated with each cognitive process (Say, Ask, and Check). Three of the students were taught the cognitive strategy first and then the metacognitive strategy. The other three students were taught the metacognitive strategy first and then the cognitive strategy. Montague found that 3 days of cognitive strategy instruction alone did not seem to improve the subjects' mathematical problem-solving performance, whereas the same amount of metacognitive strategy instruction resulted in some improvement for the three subjects who received this treatment first.

After receiving all 6 days of cognitive and metacognitive instruction, five of the six subjects showed marked improvement. Thus, the combination of both types of strategies was most effective. Follow-up generalization measures, several months after instruction, indicated that the students were unable to maintain their strategy knowledge without periodic review sessions.

In a subsequent study, Montague, Applegate, and Marquard (1993) investigated the effects of the cognitive and metacognitive strategies discussed in the preceding study on the problem-solving performance of 72 junior-high students with learning disabilities. The three treatment conditions were cognitive instruction only, metacognitive instruction 
only, and the combination of cognitive and metacognitive instruction. Two cycles of treatment were investigated in this study. The first cycle consisted of 7 days of instruction for each treatment group. The second cycle consisted of 5 days of instruction. During these 5 days, the cognitiveinstruction group now received metacognitive instruction; the metacognitive instruction group now received cognitive instruction; and the combination group continued to receive the combined instruction.

No significant difference was found between the three treatment conditions. Thus, the three conditions were collapsed to create a single treatment condition and normally achieving students were compared to students with learning disabilities. No differences were found between the two groups of students on post-instruction measures. Both groups of students improved significantly from pre- to posttest. Thus, the strategy package was effective for all of the students.

Hutchinson (1993) examined the effects of a two-phase cognitive strategy on the algebra problem solving of 20 junior-high students with learning disabilities. The students were randomly assigned to either a strategy instruction or a control group to examine the effectiveness of the algebra strategy. Hutchinson simultaneously used a repeated (ABAB) single-subject design to assess individual student learning. The cognitive strategy used in this study consisted of two phases; each phase involved the use of four questions that students were to ask and answer when solving algebraic word problems.

The four self-questions for representing algebra word problems were:

Have I read and understood each sentence?

Have I got the whole picture, a representation, for this problem?

Have I written down my representation on the worksheet?

What should I look for in a new problem to see if it is the same kind of problem?

The four self-questions for solving algebra word problems were:

Have I written an equation?

Have I expanded the terms?

Have I written out the steps of my solution on the worksheet?

What should I look for in a new problem to see if it is the same kind of problem?
Each student in the strategy group met individually with the instructor for a 40-minute session on alternate days for approximately 4 months. Scripted lessons were used to guide instruction. The lesson procedures involved stating the lesson's purpose, reviewing the self-questions, reading the word problem silently, modeling and demonstrating the strategy, providing corrective feedback, providing independent practice, and graphing progress.

The single-subject data revealed that the strategy was effective for all students in the treatment group. Posttest differences between the strategy and control group were statistically significant, favoring the strategy group.

Lambert (1997) compared the effectiveness of a cognitive problem-solving strategy to a traditional textbook method for solving three-step word problems consisting of whole numbers, decimals, fractions, and percents. A total of 76 ninth- through twelfth-grade students with learning disabilities participated in this group comparison study. The cognitive strategy group received instruction in an eightstep strategy: (a) read, (b) paraphrase, (c) visualize, (d) state the problem, (e) hypothesize, (f) estimate, (g) calculate, (h) self-check. This is a slightly modified version of the Montague and Bos (1986) strategy that also was used in Montague (1992) and Montague et al. (1993). The textbook group received instruction in a four-step method: (a) read the problem carefully, (b) plan the solution, (c) solve the problem, (d) check. Treatment for both groups included pretesting, describing and modeling the strategy or method, rehearsing the strategy steps or textbook method, and posttesting.

No significant differences were found between the cognitive strategy or the textbook method for solving three-step word problems involving whole numbers, decimals, fractions, or percentages. Lack of statistical power prevented the researcher from determining whether the treatments were effective.

Cassel and Reid (1996) investigated the effects of strategy instruction on the addition and subtraction problemsolving ability of two elementary students with learning disabilities. These researchers used a slightly modified version of Mercer and Miller's (1991-1994) FAST DRAW strategy. The modified strategy steps were to: (a) read the problem aloud; (b) find and highlight the question, then write the label; (c) ask what the parts of the problem are, then circle the numbers needed; (d) set up the problem by writing and labeling the numbers; (e) reread the problem and tie down the sign (decide if you use addition or subtraction); (f) discover the sign (recheck the operation); (g) read the number 
problem; (h) answer the number problem, and; (i) write the answer and check by asking if the answer makes sense.

These strategy steps were taught using Case, Harris, and Graham's (1992) instructional stages (see previous discussion). Strategy instruction sessions averaged 35 minutes, and occurred three times a week. The students in this multiple baseline study were taught to use the FAST DRAW strategy with two types of word problems: change/equalize and combine/compare. Both students' performance increased over baseline levels and was at or above $80 \%$ mastery level by the end of the instructional lessons. Gains were maintained at 6- and 8-week mastery checks.

\section{Use of Direct Instruction}

Wilson and Sindelar (1991) investigated the use of direct instruction for teaching addition and subtraction word problems to 62 elementary students with learning disabilities. The study had three comparison groups: strategy-plussequence, strategy-only, and sequence-only. All three groups of students received fourteen 30-minute lessons over a 3week period. The first two groups (strategy-plus-sequence and strategy-only) received instruction using a traditional direct instruction format (e.g., fast-paced lessons, teacher questioning, hand signals, choral responding). These groups were introduced to the fact-family concept and were taught to apply this concept to solving word problems. The only difference between the two direct instruction groups was that the strategy-plus-sequence group received lessons that practiced one type of word problem at a time. The first three lessons involved simple action problems. The next three lessons involved classification problems. The next three involved complex action problems, and finally comparison problems were taught.

The strategy-only group received a balanced combination of practice problems that included all four types in each lesson. The sequence-only group received word problem lessons adopted from a basal math series. During the first 15 minutes of the sequence-only lesson, the boardwork practice involved asking the students questions about the problems. Typical questions were, "What numbers are given in the problem?" or "What are we supposed to find?" Then the students had approximately 15 minutes of seatwork practice. The students in this group received instruction in one type of problem at a time in the same manner as the strategy-plussequence group. There was no statistical difference between student performance in the two direct instruction groups, and both of the direct instruction groups performed significantly better than the sequence-only group.

\section{PROBLEM-SOLVING SYNTHESIS}

Of the 14 problem-solving studies that met the criteria to be included in this review, six specifically examined the effectiveness of cognitive or metacognitive strategies, or both. These strategies provided a systematic process for students to use when attacking word problems. Students were provided a framework for thinking about the processes involved in solving word problems while simultaneously learning the procedural aspects of determining answers. When reviewing the studies involving cognitive and metacognitive strategies, several similarities were noted. First, each of the strategies had between five and eight specific steps or questions for students to use, in sequence, when solving word problems. Although the strategy steps were worded differently, similar processes emerged. Typically, students were cued to "read the problem carefully," "analyze or identify important parts of the problem," "draw or write the problem," "solve the problem," and "check the answer." In each of the studies, time was allocated for students to memorize, review, and practice the strategy steps prior to actually applying the strategy to word problems. Moreover, systematic instructional procedures (e.g., teacher demonstrations, modeling, feedback) were used to teach the strategies. Excellent student outcomes were reported in all but one of these studies.

Other problem-solving interventions that seem to hold promise for students with learning disabilities include the use of manipulative devices and drawings, schematic diagrams, and direct instruction involving fact families. It is interesting to note that, although a variety of interventions were successful in facilitating problem-solving achievement, similar teaching procedures were used in each of these studies. Typically, scripted lessons that included systematic teaching procedures such as demonstration, modeling, practice, and feedback were used to gradually guide students toward independent performance.

\section{ALTERNATIVE DELIVERY SYSTEMS}

Studies involving the use of alternative delivery systems for teaching computation and problem solving to students with learning disabilities were located during this review of literature (see Table 3). Specifically, the use of computerassisted instruction and peer tutoring will be discussed.

\section{Use of Computer-Assisted Instruction (CAI)}

Researchers interested in CAI have focused their studies on comparing CAI to teacher-directed instruction, examining 
TABLE 3

Alternative Delivery Studies

\begin{tabular}{|c|c|c|c|c|c|c|}
\hline Intervention & Citation & Subjects & Setting & Design & $\begin{array}{l}\text { Dependent } \\
\text { Measure }\end{array}$ & Results \\
\hline \multirow[t]{3}{*}{$\begin{array}{l}\text { Computer- } \\
\text { Assisted } \\
\text { Instruction } \\
\text { (CAI) }\end{array}$} & Koscinski, 1995 & 6 & $\begin{array}{l}\text { Elementary self- } \\
\text { contained class }\end{array}$ & $\begin{array}{l}\text { Parallel } \\
\text { treatments }\end{array}$ & $\begin{array}{l}\text { Criterion- } \\
\text { referenced }\end{array}$ & $\begin{array}{l}\text { Study 1: CAl and TAl were } \\
\text { comparably effective; CAI was more } \\
\text { efficient. Study 2: CAl was more } \\
\text { effective than TAI }\end{array}$ \\
\hline & Nwaizu, 1991 & 6 & $\begin{array}{l}\text { Junior high } \\
\text { resource room }\end{array}$ & $\begin{array}{l}\text { Multiple } \\
\text { baseline }\end{array}$ & $\begin{array}{l}\text { Criterion- } \\
\text { referenced }\end{array}$ & $\begin{array}{l}\text { CAI and TAI were both effective in } \\
\text { multiplication acquisition }\end{array}$ \\
\hline & $\begin{array}{l}\text { Wilson, Majsterek, \& } \\
\text { Simmons, } 1996\end{array}$ & 4 & $\begin{array}{l}\text { Elementary research- } \\
\text { only class }\end{array}$ & $\begin{array}{l}\text { Alternating } \\
\text { treatment }\end{array}$ & $\begin{array}{l}\text { Criterion- } \\
\text { referenced }\end{array}$ & $\begin{array}{l}\text { Teacher-directed instruction was more } \\
\text { effective than CAI in acquisition of } \\
\text { multiplication facts }\end{array}$ \\
\hline \multirow[t]{2}{*}{$\begin{array}{l}\text { CAl / } \\
\text { Feedback }\end{array}$} & Okolo, 1992b & 29 & $\begin{array}{l}\text { Middle school } \\
\text { resource room }\end{array}$ & $\begin{array}{l}\text { Group } \\
\text { comparison }\end{array}$ & $\begin{array}{l}\text { Criterion- } \\
\text { referenced }\end{array}$ & $\begin{array}{l}\text { Attribution retraining resulted in higher } \\
\text { computation and persistence scores } \\
\text { but did not impact student attributions }\end{array}$ \\
\hline & $\begin{array}{l}\text { Robinson, DePascale, } \\
\text { \& Roberts, } 1989\end{array}$ & 15 & $\begin{array}{l}\text { Elementary self- } \\
\text { contained class }\end{array}$ & $\begin{array}{l}\text { Group } \\
\text { comparison }\end{array}$ & $\begin{array}{l}\text { Criterion- } \\
\text { referenced }\end{array}$ & $\begin{array}{l}\text { Accuracy and number of problems } \\
\text { completed improved with feedback }\end{array}$ \\
\hline \multirow[t]{3}{*}{$\begin{array}{l}\mathrm{CAl} / \\
\text { Games }\end{array}$} & Bahr \& Rieth, 1989 & 50 & $\begin{array}{l}\text { Junior high and } \\
\text { high school } \\
\text { resource rooms }\end{array}$ & $\begin{array}{l}\text { Multiple } \\
\text { baseline }\end{array}$ & $\begin{array}{l}\text { Criterion- } \\
\text { referenced }\end{array}$ & $\begin{array}{l}\text { Two of three schools did better on } \\
\text { CAl game format than drill-and- } \\
\text { practice format }\end{array}$ \\
\hline & $\begin{array}{l}\text { Christensen \& Gerber, } \\
1990\end{array}$ & 30 & $\begin{array}{l}\text { Elementary } \\
\text { resource room }\end{array}$ & $\begin{array}{l}\text { Group } \\
\text { comparison }\end{array}$ & $\begin{array}{l}\text { Criterion- } \\
\text { referenced }\end{array}$ & $\begin{array}{l}\text { Students did better on "plain vanilla" } \\
\text { program than on arcade-type game }\end{array}$ \\
\hline & Okolo, 1992a & 41 & $\begin{array}{l}\text { Elementary self- } \\
\text { contained class }\end{array}$ & $\begin{array}{l}\text { Group } \\
\text { comparison }\end{array}$ & $\begin{array}{l}\text { Criterion- } \\
\text { referenced }\end{array}$ & $\begin{array}{l}\text { Game and drill-and-practice formats } \\
\text { improved fact fluency }\end{array}$ \\
\hline \multirow[t]{2}{*}{$\begin{array}{l}\text { CAI / } \\
\text { Strategy } \\
\text { Instruction }\end{array}$} & $\begin{array}{l}\text { Shiah, Mastropieri, } \\
\text { Scruggs, \& Fulk, } \\
\text { 1994-1995 }\end{array}$ & 30 & $\begin{array}{l}\text { Elementary schools } \\
(\mathrm{N}=8)\end{array}$ & $\begin{array}{l}\text { Group } \\
\text { comparison }\end{array}$ & $\begin{array}{l}\text { Criterion- } \\
\text { referenced }\end{array}$ & $\begin{array}{l}\text { CAI + strategy with animation, CAI + } \\
\text { strategy with static pictures, and } \\
\text { CAI + static pictures were equally } \\
\text { effective with word problems }\end{array}$ \\
\hline & Miller \& Cooke, 1989 & 8 & $\begin{array}{l}\text { Elementary general } \\
\text { education classroom }\end{array}$ & $\begin{array}{l}\text { Pre- } \\
\text { posttest } \\
\text { with control }\end{array}$ & $\begin{array}{l}\text { Criterion- } \\
\text { referenced }\end{array}$ & $\begin{array}{l}\text { Students' performance on fractions } \\
\text { was comparable to normally } \\
\text { achieving peers }\end{array}$ \\
\hline \multirow[t]{3}{*}{$\begin{array}{l}\text { Peer- } \\
\text { Tutoring } \\
\text { Techniques }\end{array}$} & Beirne-Smith, 1991 & 20 & $\begin{array}{l}\text { Elementary self- } \\
\text { contained class and } \\
\text { resource room }\end{array}$ & $\begin{array}{l}\text { Group } \\
\text { comparison }\end{array}$ & $\begin{array}{l}\text { Criterion- } \\
\text { referenced }\end{array}$ & $\begin{array}{l}\text { Cross-age tutors were equally effective } \\
\text { using a counting-on approach and } \\
\text { rote-memorization approach }\end{array}$ \\
\hline & Fasko, 1994 & 3 & $\begin{array}{l}\text { Elementary general } \\
\text { education classroom }\end{array}$ & $\begin{array}{l}\text { Multiple } \\
\text { baseline }\end{array}$ & $\begin{array}{l}\text { Criterion- } \\
\text { referenced }\end{array}$ & $\begin{array}{l}\text { Students improved multiplication } \\
\text { fluency rates and retained skills over } \\
\text { time }\end{array}$ \\
\hline & $\begin{array}{l}\text { Harper, Mallette, } \\
\text { Maheady, Bentley, \& } \\
\text { Moore, } 1995\end{array}$ & 3 & $\begin{array}{l}\text { Elementary self- } \\
\text { contained class }\end{array}$ & $\begin{array}{l}\text { Alternating } \\
\text { treatment }\end{array}$ & $\begin{array}{l}\text { Criterion- } \\
\text { referenced }\end{array}$ & $\begin{array}{l}\text { Subtraction scores improved for all } \\
\text { students; retention scores were mixed }\end{array}$ \\
\hline
\end{tabular}

entley,

Elementary self-

treatment referenced 
various types of feedback, comparing practice formats, facilitating problem-solving skills, and using videodisc instruction. Results from these studies provide insight into appropriate uses of technology for students with learning disabilities.

\section{Computer-Assisted Instruction versus Teacher-Directed Instruction}

Nwaizu (1991) investigated the effectiveness of teacherassisted instruction (TAI) and computer-assisted instruction (CAI) on the multiplication skills of six junior high school students with learning disabilities. All six subjects received both TAI and CAI instruction through multiple baseline designs. During the TAI instruction, flashcard practice was conducted to learn 10 multiplication facts. Every correct response was praised. A maximum of three teacher prompts was provided for incorrect responses. If the student failed to respond correctly after the third prompt, the teacher modeled how to solve the problem and then continued the flashcard practice with a new problem.

During the CAI instruction, computer software was used to learn 10 multiplication facts. Every correct response was praised. A maximum of three prompts was provided to incorrect responses. If the student failed to respond correctly after the third prompt, a message emerged that told the student it was a difficult item. Then the problem was solved for the student and a new problem was presented.

Students performed well under both treatment conditions. All six students reached mastery within nine instructional sessions. Intervention scores for students in the CAI condition improved $34.40 \%$ over baseline, whereas intervention scores for students in the TAI condition improved $31.33 \%$ over baseline. Students remembered an average of $79.06 \%$ of the problems mastered in TAI and $82.13 \%$ of those mastered in CAI. The CAI and TAI were equally effective in terms of the number of problems the students completed.

Koscinski (1995) conducted two studies to compare the effectiveness and efficiency of teacher-assisted instruction (TAI) to computer-assisted instruction (CAI) using the constant-time delay procedure to teach multiplication facts. Study 1 involved four elementary students with learning disabilities. A parallel-treatments design was used to introduce different sets of multiplication facts in the TAI and CAI interventions. The procedures used during TAI and CAI were: stimulus problem was presented; student read or typed the problem; specified 5-second prompt delay began; student responded correctly, incorrectly, or waited for prompt; prompt was provided, if needed, after which student repeated the problem and answered correctly, incorrectly, or did not respond; response was appropriately consequated; response type was recorded; and the next stimulus problem was presented.

Results from this study indicated that the CAI and TAI conditions were comparably effective (CAI mean effectiveness was $49.6 \%$; TAI mean effectiveness was $37.5 \%$ ). CAI was more efficient than TAI in terms of the number of sessions needed for students to reach criterion ( 6.3 sessions for CAI; 7.9 sessions for TAI). CAI and TAI were comparably effective relative to generalization across various paper/pencil tasks and an alternative mode of problem presentation.

Koscinski's second study used the same procedures and design as Study 1. In Study 2, however, changes were made to improve the equality of the multiplication facts in the two treatment conditions. Two elementary students with learning disabilities were included in Study 2. Mean effectiveness scores for the first student with learning disabilities favored the CAI treatment over TAI (CAI was $71.4 \%$; TAI mean was $52.2 \%)$. Effectiveness scores for the second student with learning disabilities also favored the CAI treatment (CAI mean was $59.3 \%$; TAI mean was $3.7 \%$ ). Both students generalized CAI facts better than TAI facts.

Wilson, Majsterek, and Simmons (1996) compared the effectiveness of computer-assisted instruction to teacherdirected instruction for teaching multiplication facts to four elementary students with learning disabilities. A single-subject, alternating treatment design was used to compare Math Blaster (Eckert \& Davidson, 1987), a popular math software program, to teacher-directed practice flashcards. Both the computer-assisted Math Blaster lessons and the teacherdirected flashcard lessons included demonstration components, guided practice, and a timed game. A total of five facts were practiced during each 30-minute lesson.

The results of this study revealed that the teacherdirected treatment was more effective than the computerassisted treatment. The magnitude of difference varied across students, ranging from $4 \%$ to $34 \%$ higher success rates in the teacher-directed lessons.

\section{Computer-Based Feedback}

Robinson, DePascale, and Roberts (1989) explored the use of a group-based technology system to provide item-byitem feedback to 15 elementary students with learning disabilities. The computer-based system used in this study was designed for group instruction. The teacher was the only person in the class with a computer. The students each had a 
standard "QWERTY"-type keyboard response device with a one-line, 32-character LED display connected to the teacher's computer. The system collected and simultaneously displayed all the students' responses to problems on the teacher's monitor. The students were instructed to work long-division problems ( 3 digits divided by 2 digits) on paper first and then to type in their answer. When feedback was delivered, it was contingent on correct answers and resulted in the student's keyboard beeping and two lights flashing. Results showed that when feedback was in force, students completed significantly more problems than when feedback was withheld, and that the level of accuracy increased from $73 \%$ to $94 \%$.

Okolo (1992b) also investigated computer-assisted feedback and the impact it had on students' attributions, persistence, and mathematics computation. Twenty nine seventhand eighth-grade students with learning disabilities participated in this study. Students in the experimental treatment group used computer software that displayed attribution retraining feedback statements such as, "You really know these", "You are really trying hard," "You can get it if you keep trying," and "You can do better if you try harder." The control-group students received neutral feedback not related to their effort, such as "You are meeting your goal," "You met your goal," "You are not meeting your goal," and "You did not meet your goal." The attribution retraining feedback did not have a significant impact on students' personal attributions, but the students who received this type of feedback completed significantly more levels of the program and obtained significantly higher scores on their math performance than the students who received neutral feedback.

\section{Computer Practice Formats}

Bahr and Rieth (1989) compared the effects of a typical drill-and-practice computer program to an instructional computer game to determine which would result in higher achievement in multiplication. The 50 students in this study were enrolled in three different schools (one high school and two junior-high schools). Each student had an identified learning disability. This multiple baseline study had three experimental conditions. Condition one was baseline and involved solving problems with paper and pencil. Condition two involved drill-and-practice using the "Build Your Skill" portion of the Math Blaster software program (Eckert \& Davidson, 1987). Math facts were presented in a nongame format, and students were given a limited amount of time to type in the answers. Condition three involved practice using an arcade-type Math Blaster game. Practice for conditions two and three occurred three times per week, for 10 minutes. In the high school and one of the junior high schools, the students performed better during the instructional game condition. There was no difference between the drill-and-practice and game format for the other junior high school students. The paper-and-pencil and computer formats were equally effective in two of the three schools. Thus, the researchers concluded that computer drill-and-practice and game formats contribute to student learning but don't necessarily produce higher achievement than non-computerbased instruction.

Christensen and Gerber (1990) also compared the use of a computer game to a more traditional drill-and-practice format. The 30 elementary students with learning disabilities in this study were assigned to either the Alien Addition (AA) group or the Plain Vanilla (PV) group. Students in the AA group played Alien Addition (Chaffin, Maxwell, \& Thompson, 1982), a commercially published microcomputer program that presents single-digit addition drill in a game format. Five addition problems appeared simultaneously at the top of the screen. As aliens moved down the screen, the students destroyed them by firing the correct answer. Students in the PV group practiced addition facts using a computer program designed in the authors' laboratory. This program presented the problems one at a time without the game and accompanying graphic elements.

Students in both groups completed 13 training sessions consisting of 6 minutes each. Automaticity was assessed in three modes of responding: oral, computer keyboard, and written. The students who used the PV practice format performed better than those who used AA in all three response modes.

Okolo (1992a) also explored the impact of an instructional computer game on students' arithmetic proficiency. Specifically, she wanted to know whether initial student attitudes toward mathematics would mediate the impact of game versus drill-and-practice formats for computerassisted instruction. The 41 fourth- through sixth-grade students with learning disabilities in this study were randomly assigned to either the game or the drill condition. Two separate sections of the Math Masters computer program (Developmental Learning Materials, 1988) were used to deliver the game and drill conditions. Student attitudes toward proficiency in math and math facts were measured prior to implementing the computer intervention. Students participated in four computer practice sessions using the practice format to which they were assigned.

Regardless of the students' initial attitude toward math or the type of practice program they used, the students' 
proficiency in arithmetic significantly improved four sessions of computer practice. The game format, however, did have a facilitative effect on the continuing motivation of students who had low attitudes toward mathematics initially.

\section{Computer-Assisted Problem Solving}

Shiah, Mastropieri, Scruggs, and Fulk (1994-1995) investigated the use of computer-assisted, cognitive-strategy instruction for solving math word problems. Their study included 30 elementary students with identified learning disabilities who were randomly assigned to one of three computer-assisted conditions: (a) word problem-solving strategy plus animation; (b) word problem-solving strategy plus static picture; and (c) no strategy, static-picture-only control. The strategy used in the first two conditions had seven steps: (a) read the problem, (b) think about the problem, (c) decide the operation sign, (d) write the math sentence, (e) do the problem, (f) label the answer, and (g) check every step.

The strategy was presented in a tutorial computer program, followed by guided and independent practice. The program features in the first two conditions were the same except animated pictures were used in the first condition and static pictures were used in the second one to help students think about the problem. The students who received the third condition (no strategy, static-picture-only control) used software programs that included a tutorial followed by guided and independent practice. The tutorial program demonstrated how to solve a word problem (without using the seven-step strategy) and included static pictures to help students think about the problem.

Students in all three conditions improved significantly from pre- to posttest on solving math word problems; no significant differences were found among the three treatment conditions. Students in all three conditions performed better on online computer tests than on paper-and-pencil tests, and no evidence of spontaneous transfer between online computer and paper-and-pencil tests was observed. All students reported enjoying the pictures and computer programs.

\section{Videodisc Instruction in Fractions}

Miller and Cooke (1989) implemented a study to determine whether students with learning disabilities could use videodisc technology to acquire computation skills with fractions while in a mainstreamed environment. Eight elementary students with learning disabilities completed 31 lessons from the Mastering Fractions videodisc program
(Systems Impact, Inc., 1985) in a general education classroom along with 15 other students. The Mastering Fractions lessons began with a paper-and-pencil quiz on concepts taught the previous day. Then a narrator reviewed previous concepts and the students responded orally to questions. New concepts were introduced at a quick pace with many opportunities for students to respond orally and on paper. The teacher's role was to monitor students' work, provide feedback, and model appropriate responding. Students used paper and pencil throughout the lessons and received homework from accompanying booklets. Ongoing assessment of student progress occurred as the lessons progressed.

The mean posttest score for the students with learning disabilities was $72 \%$, and the mean posttest score for the general education students was $78 \%$. All but one student in the class (a student with a learning disability) responded positively on a follow-up questionnaire about the videodisc program.

\section{Peer Tutoring Techniques}

Beirne-Smith (1991) explored the effects of peer tutoring on the acquisition of single-digit addition facts among 20 elementary students with learning disabilities. Specifically, she used a group comparison design to investigate the relative effectiveness of two tutoring procedures: a counting-on approach (Method A) and a rote-memorization approach (Method B).

Tutors for Method A taught and demonstrated rules related to counting-on procedures that directly addressed the interrelationship among facts (e.g., "Each time the addend increases by one, the sum increases by one."). The tutees were given opportunities to practice the rules while solving problems. Tutors for Method B used a two-task, rote-memorization procedure (e.g., "My turn, $2+6=8$. Your turn, 2 $+6=$ how many?"). Both methods included flashcard practice at the end of each tutoring session. These approaches were contrasted with one another and with a control group.

The performance of tutees in both Method A and Method B improved significantly from pre- to posttest, but no significant difference was found between the two methods. Both methods were significantly better than the no-treatment control group.

Fasko (1994) examined the effects of peer tutoring on the fluency, maintenance, and generalization of multiplication facts. Three elementary students with learning disabilities were included in her multiple baseline study. After baseline data were collected, tutors were trained and assigned to one of the tutees with learning disabilities. Peer tutoring sessions 
occurred two or three times a week for about 15 to $20 \mathrm{~min}$ utes each. A flashcard procedure was used during the tutoring sessions. The students practiced 10 facts at a time. The tutor displayed a flashcard, and the tutee had 3 seconds to respond. If correct, he was praised. If incorrect, the tutor said "no" and stated the problem and correct answer. The tutee then repeated the fact. Missed cards were marked with an " $\mathrm{X}$ " and placed back in the deck. After all 10 cards were shown (and any repeats), the tutor marked the correct cards with an 0 . The process was repeated with the same 10 cards.

At the end of the tutoring session, a line was drawn under the X's and 0's to separate each day's marks. When a card had five 0 's in a row, the fact was considered mastered and was replaced with a new fact. A charting procedure was used to document the number of facts mastered. All three students improved their fluency rates and maintained their performance over several weeks. Moreover, the students generalized their performance to class worksheets.

Harper, Mallette, Maheady, Bentley, and Moore (1995) investigated the effects of classwide peer tutoring (CWPT) on retention of subtraction facts. Three elementary students with learning disabilities were included in this study. The researchers used a variant of the alternating treatment design to assess the peer tutoring procedure. Students with similar math abilities were assigned to dyads.

From a list of 10 problems, the tutor orally presented a subtraction problem to the tutee. The tutee wrote the problem and solution. If the answer was correct, the tutor awarded two points. If incorrect, the tutee rewrote the problem with the correct answer three times and earned one point. If the tutee refused to correct his or her response, no points were awarded. After 5 minutes of this type of practice, the tutor and tutee roles were reversed and the same procedure was used. The students' pretest scores were $43 \%$, $88 \%$, and $40 \%$. Their posttest scores were $97 \%, 98 \%$, and $100 \%$. Retention scores 1 week after the intervention was discontinued were $77 \%, 95 \%$, and $97 \%$ respectively.

\section{SYNTHESIS OF ALTERNATIVE DELIVERY SYSTEMS}

Most research indicates that computer-assisted instruction and peer tutoring are effective methods for providing instructional practice to students with learning disabilities. Findings were mixed relative to the effectiveness of teacherassisted instruction versus computer-assisted instruction. Results from one study suggested that both TAI and CAI were effective, results from two studies favored CAI, and results from one other study favored TAI. Findings were also mixed, and therefore, inconclusive with regard to the best format for computer-assisted practice. The results of two studies indicated that both game and nongame drill-andpractice formats were effective for increasing student achievement; the results of a third study indicated that the nongame drill-and-practice format was more effective.

Studies revealed that a variety of peer tutoring practice formats were effective. Included among these were counting-on procedures, rote memorization, oral and written drills, and practice using flashcards. Corrective feedback was important in both computer-assisted and peer tutoring delivery systems.

\section{DISCUSSION}

Clearly, the amount of research related to teaching math to students with learning disabilities has increased over the past decade. A previous review (Mastropieri, Scruggs, \& Shiah, 1991), located 30 studies published during a 13-year period (1975-1988). In the current review, we located 54 studies published during a 9-year period (1988-1997). This increased focus on mathematics instruction is certainly warranted given the importance of math skills in everyday life and the traditionally poor math performance of students with learning disabilities.

Based on this review of literature, several interventions emerged as effective for both computation and problemsolving instruction. Foremost among these are strategy and self-regulation interventions. Students with learning disabilities clearly benefited from step-by-step processes that guided their thinking and performance when solving math problems. These interventions promoted student independence and increased math achievement. The use of manipulative devices and drawings also emerged as an effective practice for teaching both computation and word problems. Manipulative devices with and without subsequent drawings were effective.

Findings related to the use of drawings without manipulative devices, however, were mixed. Direct instruction (scripted lessons, fast-pace, choral responding, hand signals, much repetition) and direct instruction formats (demonstration, modeling, guided practice, independent practice, feedback) were also effective. Finally, the use of computerassisted instruction holds promise for achievement in both computation and problem solving.

A few interventions emerged as being particularly appropriate for instruction in computation. Included among these 
were constant time delay, lecture pause, peer tutoring, and use of goal structures to facilitate motivation and achievement. It is interesting to note that, regardless of the intervention, similar instructional procedures were used in the studies reviewed. Consistently used were teacher demonstrations; opportunities for students to model; guided practice with teacher, student, or computer feedback; independent practice; and ongoing measurement of student progress.

From this review, most of the research in mathematics instruction for students with learning disabilities clearly has focused on computation and problem solving involving addition, subtraction, multiplication, and division. Minimal work has been done related to algebra, money skills, and fractions. Future research should investigate the application of validated practices in computation and problem solving to math skills that extend beyond the four basic operations. These include fractions, decimals, percentages, time, money, measurement, geometry, and algebra. Moreover, further refinement of these procedures and additional group comparison studies would contribute to the existing knowledge base.

\section{REFERENCES}

Ackerman, P. T., Anhalt, J. M., \& Dykman, R. A. (1986). Arithmetic automatization failure in children with attention and reading disorders: Associations and sequelae. Journal of Learning Disabilities, 19, 222-232.

Badian, N. A. (1983). Dyscalculia and nonverbal disorders of learning. In H. R. Myklebust (Ed.), Progress in learning disabilities (Vol. 5, pp. 235-264). New York: Grune \& Stratton.

*Bahr, C. M., \& Rieth, H. J. (1989). The effects of instructional computer games and drill and practice software on learning disabled students' mathematics achievement. Computers in the Schools, 6, (3/4), 87-101.

*Baker, D. E. (1993). The effect of self-generated drawings on the ability of students with learning disabilities to solve mathematical word problems. (Doctoral dissertation, Texas Tech University, 1992). Dissertation Abstracts International, 53, 2762.

*Beirne-Smith, M. (1991). Peer tutoring in arithmetic for children with learning disabilities. Exceptional Children, 57, 330-337.

Brian, T., Bay, M., Lopez-Reyna, N., \& Donahue, M. (1991). Characteristics of students with learning disabilities: A summary of the extant data base and its implications for educational programs. In J. W. Lloyd, N. Nirbhay, \& A. C. Repp (Eds.), The Regular Education Initiative: Alternative perspectives on concepts, issues, and models (pp. 113131). Sycamore, IL: Sycamore.

*Brown, D., \& Frank, A. R. (1990). Let me do it!-Self-monitoring in solving arithmetic problems. Education \& Treatment of Children, 13, 239-248.

*Bryan, T., \& Bryan, J. (1991). Positive mood and math performance. Journal of Learning Disabilities, 24, 490-494.

*Case, L. P., Harris, K. R., \& Graham, S. (1992). Improving the mathematical problem-solving skills of students with learning disabilities: Self-regulated strategy development. Journal of Special Education, 26 (1), 1-19.
*Cassel, J., \& Reid, R. (1996). Use of a self-regulated strategy intervention to improve word problem-solving skills of students with mild disabilities. Journal of Behavioral Education, 6,153-172.

Cawley, J. F., \& Miller, J. H. (1989). Cross-sectional comparisons of the mathematical performance of children with learning disabilities: Are we on the right track toward comprehensive programming? Journal of Learning Disabilities, 22, 250-259.

Cawley, J. F., Parmar, R. S., Yan, W. F., \& Miller, J. H. (1996). Arithmetic computation abilities of students with learning disabilities: Implications for instruction. Learning Disabilities Research \& Practice, 11, 230-237.

Cawley, J. F., Parmar, R. S., Yan, W. F., \& Miller, J. H. (1998). Arithmetic computation performance of students with learning disabilities: Implications for curriculum. Learning Disabilities Research \& Practice, 13, 68-74.

Chaffin, J. D., Maxwell, M. S., \& Thompson, B. (1982). Academic skill builders in math: Teacher's manual. Allen, TX: Developmental Learning Materials.

*Christensen, C. A., \& Gerber, M. M. (1990) Effectiveness of computerized drill and practice games in teaching basic math facts. Exceptionality, 1, 149-165.

Developmental Learning Materials (1988). Math masters [Computer program]. Allen, TX: Author.

*Dunlap, L. K., \& Dunlap, G. (1989). A self-monitoring package for teaching subtraction with regrouping to students with learning disabilities. Journal of Applied Behavior Analysis, 22, 309-314.

Eckert, R. \& Davidson, J. (1987). Math blaster plus [Computer software]. Torrance, CA: Davidson \& Associates.

*Fasko, S. N. (1994), The effects of a peer tutoring program on math fact recall and generalization. Paper presented at annual meeting of American Psychological Association, Los Angeles.

Fleischner, J. E., Garnett, K., \& Shepherd, M. (1982). Proficiency in arithmetic basic fact computation by learning disabled and nondisabled children. Focus on Learning Problems in Mathematics, 4, 47-55.

*Fuchs, L. S., Bahr, C. M., \& Rieth, H. J. (1989). Effects of goal structures and performance contingencies on the math performance of adolescents with learning disabilities. Journal of Learning Disabilities, 22, 554-560.

*Fuchs, L. S., Fuchs, D., Hamlett, D. L., \& Whinnery, K. (1991). Effects of goal line feedback on level, slope, and stability of performance within curriculum-based measurement. Learning Disabilities Research \& Practice, 6, 66-74.

*Funkhouser, C. (1995). Developing number sense and basic computational skills in students with special needs. School Science and Mathematics, 95, 236-239.

Goldman, S. R. (1989). Strategy instruction in mathematics. Learning Disability Quarterly, 12, 43-55.

*Harper, G. F., Mallette, B., Maheady, L., Bentley, A. E., \& Moore, J. (1995). Retention and treatment failure in classwide peer tutoring: Implications for future research. Journal of Behavioral Education, 5, $399-414$.

*Harris, C. A., Miller, S. P., \& Mercer, C. D. (1995). Teaching initial multiplication skills to students with disabilities in general education classrooms. Learning Disabilities Research \& Practice, 10,180-195.

*Hastings, F. L., Raymond, G., \& McLaughlin, T. F. (1989). Speed counting money: The use of direct instruction to train learning disabled and mentally retarded adolescents to count money efficiently. B. C. Journal of Special Education, 13, 137-146. 
*Hawkins, J., Brady, M. P., Hamilton, R., Williams, R. E., \& Taylor, R. D. (1994). The effects of independent and peer guided practice during instructional pauses on the academic performance of students with mild handicaps. Education \& Treatment of Children, 17, 1-28.

*Holmes, S. R. R. (1991). The effect of verbal self-instructional training on the mathematical performance of fifth and sixth grade learning disabled children in a group compared to individualized instructions (Doctoral dissertation, Southern Illinois University at Carbondale, 1990). Dissertation Abstracts International, 52, 1709.

*Huntington, D. J. (1995). Instruction in concrete, semi-concrete, and abstract representation as an aid to the solution of relational problems by adolescents with learning disabilities (Doctoral dissertation, University of Georgia, 1994). Dissertation Abstracts International, 56, 512.

*Hutchinson, N. L. (1993). Effects of cognitive strategy instruction on algebra problem solving of adolescents with learning disabilities. Learning Disabilities Quarterly, 16, 34-63.

*Jitendra, A. K., \& Hoff, K. (1996). The effects of schema-based instruction on the mathematical word-problem-solving performance of students with learning disabilities. Journal of Learning Disabilities, 29 , 442-431.

*Koscinski, S. T. (1995). Comparison of teacher-assisted and computerassisted instruction using constant time delay to teach multiplication facts to students with mild disabilities. (Doctoral dissertation, University of Georgia, 1994). Dissertation Abstracts International, 55, 3810.

*Koscinski, S. T., \& Gast, D. L. (1993a). Computer-assisted instruction with constant time-delay to teach multiplication facts to students with learning disabilities. Learning Disabilities Research \& Practice, 8, 157-168.

Koscinski, S. T., \& Gast, D. L. (1993b). Use of constant time delay in teaching multiplication facts to students with learning disabilities. Journal of Learning Disabilities, 26, 533- 544.

*Laird, J., \& Winton, A. S. W. (1993). A comparison of self-instructional checking procedures for remediating mathematical deficits. Journal of Behavioral Sciences, 3, 143-164.

*Lambert, M. A. (1997). Teaching students with learning disabilities to solve word-problems: A comparison of a cognitive strategy and a traditional textbook method (doctoral dissertation, Florida Atlantic University, 1996). Dissertation Abstracts International, 57, 2966.

Lee, W. M., \& Hudson, F. G. (1981). A comparison of verbal problem-solving in arithmetic of learning disabled and non-learning disabled seventh grade males (Research Report No. 43). Lawrence: University of Kansas, Institute for Research in Learning Disabilities.

McLeod, T., \& Armstrong, S. (1982). Learning disabilities in mathematics-skill deficits and remedial approaches at the intermediate and secondary grades. Learning Disability Quarterly, 5, 305-311.

*Marsh, L. G., \& Cooke, N. L. (1996). The effects of using manipulatives in teaching math problem solving to students with learning disabilities. Learning Disabilities Research \& Practice, 11, 58-65.

Mastropieri, M. A., Scruggs, T. E., \& Shiah, S. (1991). Mathematics instruction for learning disabled students: A review of research. Learning Disabilities Research \& Practice, 6, 89-98.

Mercer, C. D., \& Miller, S. P. (1991-1994). Strategic math series. Lawrence, KS: Edge Enterprises.

*Miller, S. C., \& Cooke, N. L. (1989). Mainstreaming students with learning disabilities for videodisc math instruction. Teaching Exceptional Children, 21 (3), 57-60.
*Miller, S. P., \& Mercer, C. D. (1993a). Using a graduated word problem sequence to promote problem-solving skills. Learning Disabilities Research \& Practice, 8, 169-174.

* Miller, S. P., \& Mercer, C. D. (1993b). Using data to learn about concretesemiconcrete-abstract instruction for students with math disabilities. Learning Disabilities Research \& Practice, 8, 89-96.

*Montague, M. (1992) The effects of cognitive and metacognitive strategy instruction on the mathematical problem solving of middle school students with learning disabilities. Journal of Learning Disabilities, 25, 230-244.

*Montague, M., Applegate, B., \& Marquard, K. (1993). Cognitive strategy instruction and mathematical problem-solving performance of students with learning disabilities. Learning Disabilities Research \& Practice, 8, 223-232.

Montague, M., \& Bos, C. (1986). The effect of cognitive strategy training on verbal math problem-solving performance of learning disabled adolescents. Journal of Learning Disabilities, 1, 26-33.

*Morton, R. C., \& Flynn, S. W. (1997). A comparison of constant time delay and prompt fading to teach multiplication facts to students with learning disabilities. Journal of Instructional Psychology, 24, 3-13.

*Naglieri, J. A., \& Gottling, S. H. (1995). A study of planning and mathematics instruction for students with learning disabilities. Psychological Reports, 76, 1343-1354.

*Naglieri, J. A., \& Gottling, S. H. (1997). Mathematics instruction and PASS cognitive processes: An intervention study. Journal of Learning Disabilities, 30, 513-520.

National Council of Teachers of Mathematics. (1989). Curriculum and evaluation standards for school mathematics. Reston, VA: Author.

*Nwaizu, P. C. I. (1991). Using teacher-assisted and computer-assisted instruction to teach multiplication skills to youths with specific learning disabilities (doctoral dissertation, University of New Orleans, 1990). Dissertation Abstracts International, 51, 3041.

*Okolo, C. M. (1992a). The effect of computer-assisted instruction format and initial attitude on the arithmetic facts proficiency and continuing motivation of students with learning disabilities. Exceptionality, 3,195211.

*Okolo, C. M. (1992b). The effects of computer-based attribution retraining on the attributions, persistence, and mathematics computation of students with learning disabilities. Journal of Learning Disabilities, 25, 327-334.

*Peterson, S. K., Mercer, C. D., \& O'Shea, L. (1988). Teaching learning disabled students place value using the concrete to abstract sequence. Learning Disabilities Research, 4, 52-56.

*Rivera, D., \& Smith, D. D. (1988). Using a demonstration strategy to teach middle school students with learning disabilities how to compute long division. Journal of Learning Disabilities, 21, 77-81.

*Robinson, S. L., DePascale, C., \& Roberts, F. C. (1989). Computer-delivered feedback in group-based instruction: Effects for learning disabled students in mathematics. Learning Disabilities Focus, 5 (1), 28-35.

*Ross, P. A., \& Braden, J. P. (1991). The effects of token reinforcement versus cognitive behavior modification on learning-disabled students' math skills. Psychology in the Schools, 28, 247-256.

*Shiah, R. L., Mastropieri, M. A., Scruggs, T. E., \& Fulk, B. J. M. (19941995). The effects of computer-assisted instruction on the mathematical problem solving of students with learning disabilities. Exceptionality, 5,131-161.

Systems Impact, Inc. (1985). Mastering fractions. Washington, DC: Author. 
*Van Houten, R. (1993). Rote vs. rules: A comparison of two teaching and correction strategies for teaching basic subtraction facts. Education and Treatment of Children, 16,147-159.

*Van Houten, R., \& Rolider, A. (1990). The use of color mediation techniques to teach number identification and single digit multiplication problems to children with learning problems. Education and Treatment of Children, 13, 216-224.

*Walker, D. W., \& Poteet, J. A. (1989-1990). A comparison of two methods of teaching mathematics story problem-solving with learning disabled students. National Forum of Special Education Journal, 1 (1) 44-51.

Warner, M., Alley, G., Schumaker, J., Deshler, D., \& Clark, F. (1980). An epidemiological study of learning disabled adolescents in secondary schools: Achievement and ability, socioeconomic status and school experiences (Report No. 13). Lawrence: University of Kansas, Institute for Research in Learning Disabilities.

*Whinnery, K. W., \& Fuchs, L. S. (1993). Effects of goal and test-taking strategies on the computation performance of students with learning disabilities. Learning Disabilities Research \& Practice, 8, 204-214.

*Williams, D. M., \& Collins, B. V.(1994).Teaching multiplication facts to students with learning disabilities: Teacher-selected versus studentselected material prompts within the delay procedure. Journal of Learning Disabilities, 27, 589-597.
*Wilson, C. L., \& Sindelar, P. T. (1991). Direct instruction in math word problems: Students with learning disabilities. Exceptional Children, 57, 512-519.

*Wilson, R., Majsterek, D., \& Simmons, D., (1996). The effects of computer-assisted versus teacher-directed instruction on the multiplication performance of elementary students with learning disabilities. Journal of Learning Disabilities, 29, 382-390.

*Wood, D. A., Rosenberg, M. S., \& Carran, D. T. (1993). The effects of tape-recorded self-instruction cues on the mathematics performance of students with learning disabilities. Journal of Learning Disabilities, 26, 250-258.

Zentall, S. S., \& Ferkis, M. A. (1993). Mathematical problem solving for youth with ADHD, with and without learning disabilities. Learning Disability Quarterly, 16, 6-17.

*References marked with an asterisk indicate studies included in the review. 